Article

\title{
High-Tech Urban Agriculture in Amsterdam: An Actor Network Analysis
}

\author{
Mohsen H. Farhangi $1, * \mathbb{C}$, Margherita E. Turvani ${ }^{2}$, Arnold van der Valk ${ }^{3}$ and \\ Gerrit J. Carsjens ${ }^{3}$ (1) \\ 1 Department of Thematic Studies-Division of Technology and Social Change, Linköping University, \\ SE-581 83 Linköping, Sweden \\ 2 Department of Architecture and Arts, University IUAV of Venice, 30135 Venice, Italy; margheri@iuav.it \\ 3 Landscape Architecture and Spatial Planning Group, Wageningen University \& Research, P.O. Box 47, \\ 6700 AA Wageningen, The Netherlands; arnold.vandervalk@wur.nl (A.v.d.V.); \\ gerrit-jan.carsjens@wur.nl (G.J.C.) \\ * Correspondence: mohsen.h.farhangi@gmail.com; Tel.: +31-682-742-596
}

Received: 12 March 2020; Accepted: 8 May 2020; Published: 12 May 2020

check for updates

\begin{abstract}
The agriculture and horticulture sector in the Netherlands is one of the most productive in the world. Although the sector is one of the most advanced and intense agricultural production systems worldwide, it faces challenges, such as climate change and environmental and social unsustainability of industrial production. To overcome these challenges, alternative food production initiatives have emerged, especially in large cities such as Amsterdam. Some initiatives involve producing food in the urban environment, supported by new technologies and practices, so-called high-tech urban agriculture (HTUA). These initiatives make cultivation of plants inside and on top of buildings possible and increase green spaces in urban areas. The emerging agricultural technologies are creating new business environments that are shape $d$ by technology developers (e.g., suppliers of horticultural light emitting diodes (LED) and control environment systems) and developers of alternative food production practices (e.g., HTUA start-ups). However, research shows that the uptake of these technological innovations in urban planning processes is problematic. Therefore, this research analyzes the barriers that local government planners and HTUA developers are facing in the embedding of HTUA in urban planning processes, using the city of Amsterdam as a case study. This study draws on actor-network theory (ANT) to analyze the interactions between planners, technologies, technology developers and developers of alternative food production practices. Several concepts of ANT are integrated into a multi-level perspective on sustainability transitions (MLP) to create a new theoretical framework that can explain how interactions between technologies and planning actors transform the incumbent social-technical regime. The configuration of interactions between social and material entities in technology development and adoption processes in Amsterdam is analyzed through the lens of this theoretical framework. The data in this study were gathered by tracing actors and their connections by using ethnographic research methods. In the course of the integration of new technologies into urban planning practices, gaps between technologies, technology developers, and planning actors have been identified. The results of this study show a lacking connection between planning actors and technology developers, although planning actors do interact with developers of alternative food production practices. These interactions are influenced by agency of artefacts such as visualizations of the future projects. The paper concludes that for the utilization of emerging technologies for sustainability transition of cities, the existing gap between technology developers and planning actors needs to be bridged through the integration of technology development visions in urban agendas and planning processes.
\end{abstract}


Keywords: technology driven transition; actor-network theory; multi-level perspective; urban planning; high-tech urban agriculture

\section{Introduction}

The agriculture and horticulture sectors in the Netherlands are considered among the most efficient and productive across the globe [1]. The Netherlands is ranked as the second greatest exporter of both agricultural and horticultural goods worldwide [2]. The farming sector is highly intensive and specialized with a high level of technologies and knowledge. Dutch agriculture relies on other countries for importing raw materials and exporting agricultural goods. The development of the Netherlands' agricultural sector is highly affected by European-level policies (i.e., the Common Agricultural Policy (CAP)), and national-level policies [3,4]. Although the Dutch agricultural sector is highly advanced, it faces a number of challenges, such as climate change [5]. In addition, in the past decades, the agricultural sector advancement resulted in the development of large-scale industrial farms. The environmental and social unsustainability of such farms has become a concern for authorities in the Netherlands [6]. To overcome the challenges of the agricultural sector, many initiatives have emerged in the Netherlands, especially in large cities such as Amsterdam, which is one of the pioneers in terms of the development of the strategies and promotion of alternative urban food systems in the Netherlands [7].

High-tech urban agriculture (HTUA) in Amsterdam is an alternative food production strategy that has attracted much attention from the private sectors and government. HTUA practices are urban food production initiatives that apply advanced horticultural technologies such as soilless cultivation systems (e.g., hydroponics, aeroponics), controlled environment system and horticultural light emitting diode (LED) lighting to adjust the indoor environment for growth of plants and to make growing food vertically inside built-up spaces feasible. HTUA practices are intensive vegetable and herb production practices that include cultivation, harvest and post-harvest processes [8]. Besides the social and environmental benefits of local food production in cities (e.g., education, awareness about the source of food and less transportation and post-harvest processes), HTUA practices are highly water and land efficient. They use $90 \%$ less water and produce 20 times more food than incumbent agro food production practices $[9,10]$. HTUA practices are also criticized for their high energy consumption [11,12]. However, the advocates of HTUA believe that further advancements in agricultural technologies can reduce the energy consumption in HTUA [10].

HTUA practices are one type of building-integrated agriculture [13]. Bringing agriculture into the built environment changes the relationships between urban residents, agriculture, food, and the landscape. HTUA contributes to the creation of a "productive green infrastructure for social wellbeing" through "local food production" and "improving the health of urban residents" [14] (p. 160). Gould and Caplow [13] argue that these kinds of practices have "the potential to significantly reduce fossil fuel consumption, improve urban ecology, enhance food safety and security, enrich the lives of city dwellers and conserve building energy" [13] (p. 150).

Many initiatives have emerged through collaboration between the private and public sectors in Amsterdam to bring vertical farms, indoor gardens, roof top greenhouses, and many other types of HTUA practices inside Amsterdam's urban boundaries. HTUA practices in Amsterdam are mainly multifunctional indoor farms, self-sufficient eco villages, and vertical farms with low return on investments, but are focused on climate change resiliency, circularity, and social and environmental aspects of urban agriculture. Many start-ups such as Vegger, GrowX, Onefarm, Priva, ReGen villages, and Grown Downtown, began their activities as HTUA initiatives through public-private partnerships and with financial support from national and local subsidies and incentives [15].

The emerging agricultural technologies are creating new business environments that are shaped by technology developers (e.g., suppliers of horticultural light emitting diodes (LED) and control 
environment systems) and developers of alternative food production practices (e.g., HTUA start-ups). However, research shows that the uptake of these technological innovations in urban planning processes is problematic and needs further research $[8,16,17]$. Therefore, this paper analyzes the barriers that local government planners and HTUA developers are facing in the embedding of HTUA in urban planning processes, using the city of Amsterdam as a case study. To identify the institutional barriers and driving forces of technology-driven transition, this paper analyzes the interactions among social and materials entities that are involved in the transition process of urban food production practices in Amsterdam. It studies the role of both human and nonhuman actors in the reconfiguration of relationships in the sociotechnical system to create new food production systems in Amsterdam. It focuses especially on the development of agricultural technologies and their adoption in urban practices. The technology-driven transition framework, developed by Hosseinifarhangi et al. (2019), is used as a conceptual framework. This framework combines the theory of multi-level perspective (MLP) on sustainability transitions and actor-network theory (ANT). The paper aims to improve the framework by removing some of its ambiguities.

\section{The Technology-Driven Transition Framework}

This study draws on the technology-driven transition framework for analyzing the transition trajectories in food production practices in Amsterdam. The technology-driven transition framework is shaped by a combination of actor-network theory (ANT) and multi-level perspective (MLP) on sustainability transitions. The MLP's transition model conceptualizes the transition process by defining three analytical levels: niches, socio-technical regimes and the socio-technical landscape $[16,18]$. In the MLP framework, transition is the "result of two driving forces, the pressure from the sociotechnical landscape (the exogenous environment of cultural patterns and macrolevel economics and politics) and the alignment of small networks of niche innovations and actors. When both come together, so-called windows of opportunity arise for destabilizing existing sociotechnical regimes and a breakthrough of new sociotechnical regimes occurs" [8] (p. 30). ANT is applied in transition studies to analyze the agency of social and material entities and the creation of actor-networks that emerge to transform the incumbent sociotechnical systems $[19,20]$. To conceptualize transition trajectories, two principles of ANT, flat ontology and generalized symmetry, are applied in this study. Generalized symmetry does not consider any differences in attribution of agency by human and non-human actants and analyzes them in equal conceptual frameworks. An actant is any entity that acts or can assign an action. The flat ontology emphasizes that each entity is an actant and an actor-network at the same time and defines actants (social and material entities) by their relationships. This study emphasizes the role of nonhumans (i.e., technologies and artefacts) in the mobilization of social entities in transition processes. It studies the transition as a process in which new actor-networks are shaped.

The integration of MLP and ANT helps to conceptualize the trajectories of technology-driven transitions. It tends to explain how technological novelties emerge and change the sociotechnical systems. It looks at both bottom-up and top-down transition pathways. The combination of the flat ontology of ANT and the analytical levels of MLP allows studying both bottom-up and top-down strategies within the same framework. By applying the ANT's conceptual framework, all actants with agency are considered relevant to the study and actants are not limited to a specific context. However, in the technology-driven transitions the impact of the context is not ignored. The impact of social, political, cultural, and environmental contexts on transition processes is studied through analyzing their impact on the agency of actants that shape the actor-network of transition. MLP levels categorize the actants, for simplification of analyses, but they do not have any influence on their agency and beingness. Furthermore, the concept of immutable mobiles is taken from ANT to study the role of nonhumans in the transition process. Immutable mobile refers to those properties of an artefact that do not change when "passing through time and space. An immutable mobile is something that can be interpreted in the same manner in different contexts, and is not context-dependent" [8] (p. 5). Guggenheim [21] introduced immutable mobiles as "highly modern objects, dependent on science to 
invent them, metrologies to measure and standardize them and standardized production lines to bring them into being" [21] (p. 69).

Hosseinifarhangi et al. (2019) [8] defined three stages of technology-driven transitions. These three stages are: (1) Disentanglement of the incumbent regime; (2) Punctualization process of novelties; and (3) Re-entanglement of punctualized actor-networks and the creation of a new sociotechnical regime (Figure 1).

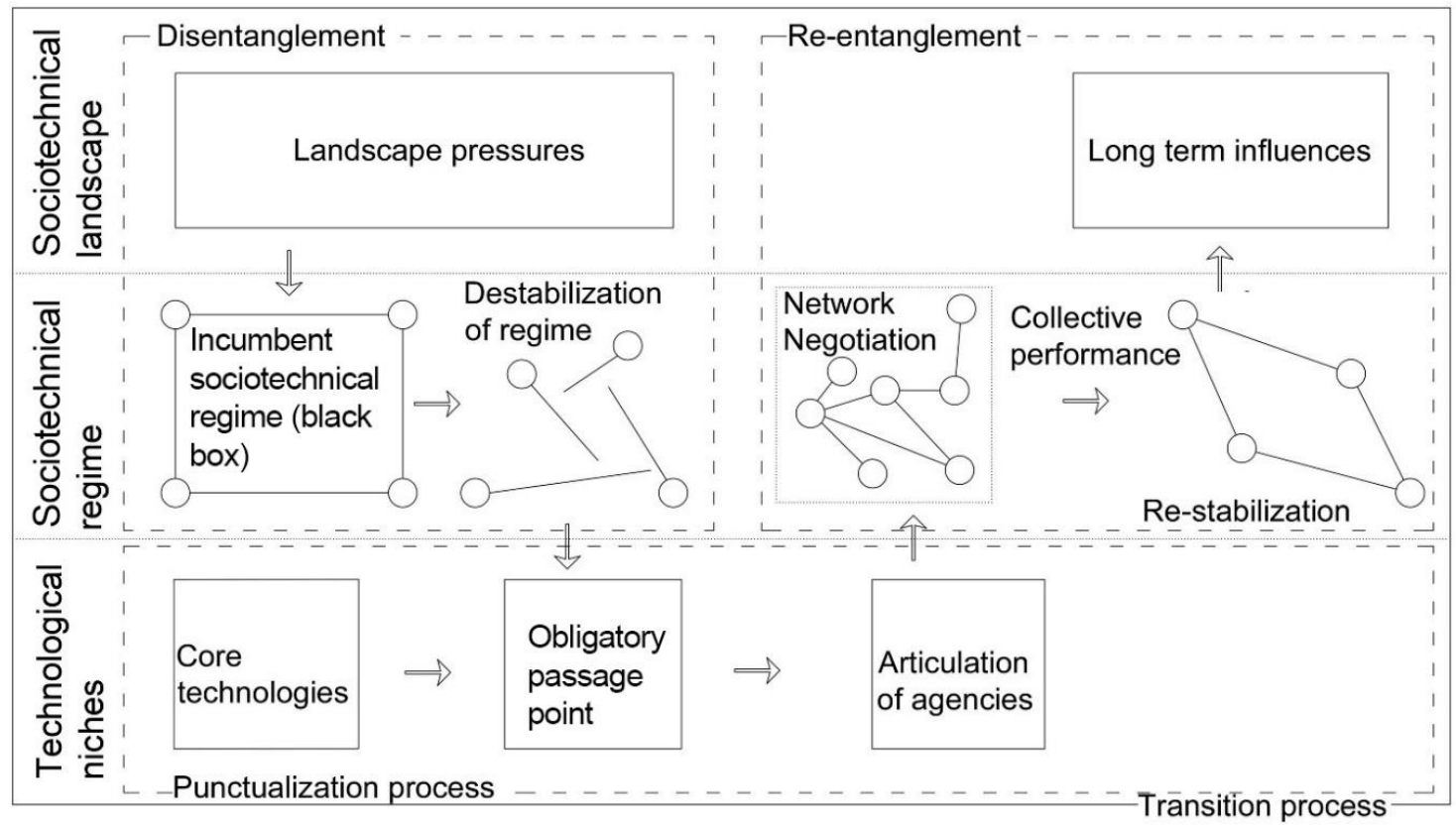

Figure 1. The three stages of the transition process [8].

1. Disentanglement of the incumbent regime includes processes in which the current sociotechnical system becomes destabilized. The destabilization in this stage is the result of niche and landscape pressures.

2. The punctualization process of novelties happens through the process of translation. In the translation process of ANT, the relationships between human and non-human actants of the sociotechnical system are reconfigured. The reconfiguration of relationships among social and materials entities happens in four moments: problematization, interessement, enrolment and mobilization. In the first moment, problematization, a focal actant emerges and identifies the problems that make the transition inevitable. The focal actant defines an obligatory passage point (OPP), which makes itself an indispensable actant in the transition processes. OPPs are the focal actants' initiative "for creation of an entry point for all other interested actors and formation of a network of aligned interests. An OPP can be a project, technology, an entity, or any human or nonhuman actor" [22]. In the interessement moment, the focal actant tries to find allies for creation of the actor network of transition [20]. In the third moment, enrolment, the focal actor uses different strategies to make the allies that join the actor network of transition loyal to their roles and identity in the transition process. The last moment, mobilization, includes the representation of the actor network as a legitimate entity for resolving the challenges of the incumbent sociotechnical regime [23].

3. Re-entanglement of punctualized actor-networks and the creation of a new sociotechnical regime is the final stage of the transition. In this stage the innovations are diffused and become part of the sociotechnical system. The re-entanglement of sociotechnical systems may take a long time, in which novelties try to replace the incumbent technologies or complement them [8]. 
The transition is a result of new relations. The relations are not a simple linear connection between two actants. Relations are established by expanding actor-networks. In technology-driven transitions, the novelties will become part of sociotechnical systems through the creation of assemblages (connecting actor-networks) that are influenced by business ecosystems (Figure 2).

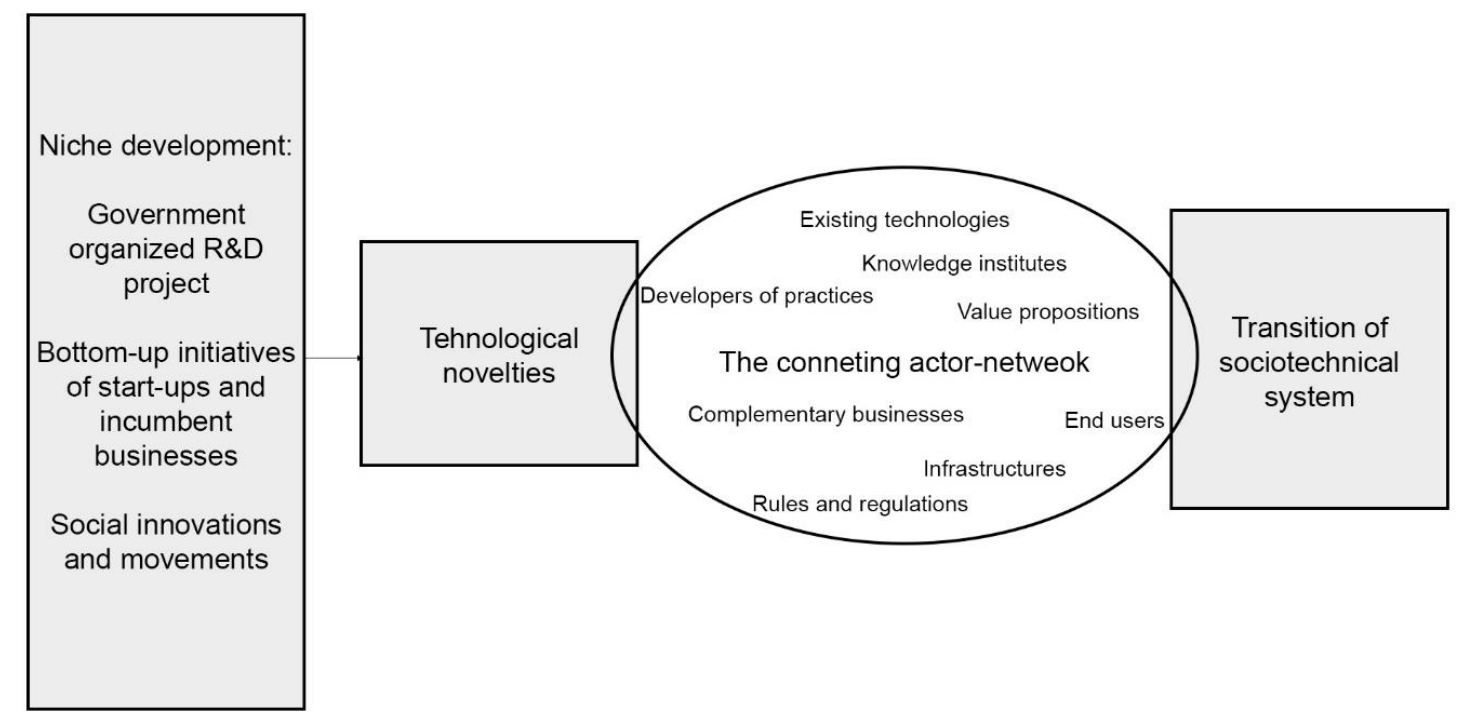

Figure 2. Transformation of sociotechnical systems in technology-driven transitions.

In this framework, transition is considered as a successful expansion of actor-networks or the creation of new assemblages in current socio-technical systems. These assemblages are not only created by the introduction of technological novelties in the current sociotechnical regime. They are a result of the establishment of new relationships between social and materials entities. These entities can be existing actants, of which relationships with other human and nonhuman actants are reconfigured. They can also be novelties that are introduced by niche developers. In this case, business plans and value propositions of niche developers define their relationships with other actants involved in the transition processes.

Disentanglement of sociotechnical regimes is a result if disruption of relationships among actants is involved in the sociotechnical system. These disruptions can be a consequence of landscape pressure on the regime and the niche level or a result of opportunities that are offered by alternative systems to the regime. The disentanglement of the sociotechnical regime provides opportunities for niche actants to expand their network and to create new connections with actants beyond the niche level. Niches are created through government organized R\&Ds, bottom-up initiatives of incumbent businesses and start-ups. They reach the sociotechnical regime through the expansion of networks of niche developers into the current regime. This happens through punctualization of novelties in the regime level. The agency of niche developers and their value propositions can reconfigure the relationships among other actants in the regime level. The reconfiguration of relationships occurs during the four translation moments. Technological novelties will be defined as an obligatory passage point by the niche developer (focal actant). The potential of value propositions is an influential factor in the interessement moment of translation and the enrolment of allies in the actor-network of transition. The feasibility of business plans and their implementation will play a main role in mobilization of the actor-network. Re-entanglement is a continuous effort during the transition process, mobilizing actants for local diffusion of novelties through creation of new business ecosystems around novelties. By defining a clear pathway for technology-driven transitions and introducing the connecting actor-networks this paper tries to improve the theoretical frameworks that were introduced by authors of this paper in 2019 [8]. 


\section{Methodology}

To analyze the technology-driven transition in Amsterdam's food production practices, this study used an exploratory case study research. Ethnography research methods were used to study the interactions between various human and non-human actors involved in the transition process. The data were gathered through semi-structured interviews (Please see Appendix A, Table A2), documents reviews (Table A1), site visits and observations (Table A3) and participation in R\&D development projects. The empirical studies were done between June 2016 and February 2018.

This study draws on ANT as a conceptual framework. The actants (human and non-human actors) that are studied are divided into four categories: (1) Human and associations; (2) Representatives of nature; (3) Technologies; (4) Buildings and structures. By applying the ANT's principles to study the actor-networks of transition, the relationship of actants that shape them are analyzed. This study investigated these relationships by tracing the actants involved. The initial actants that were selected for tracing the relationships and interactions in transition process were researchers at the Applied Science University of Amsterdam and the Amsterdam Institute for Advanced Metropolitan Solutions, and start-up niche developers (Mediamatic, Vegger and GrowX). Through snowballing (chain referral method) other actants that were involved in the transition process and experts that were familiar with non-human actants involved were identified and their relationships with other involved actants were traced. Two different groups (technology developers and researchers) were selected as the initial point of study to avoid limiting the study to one group's point of view and network. In the tracing process through snowballing, the interviewees were asked to refer other social and material entities (individuals, organizations, documents and locations) that should be investigated. Informal discussions and observations during site visits and document reviews and semi-structured interviews were used to gather information about the identity and relationships of referred actants. Through the information that was gathered, a list of involved actants was made and their degree of relevance defined. The degree of relevance is an indicator that states the influence of the actant on the transition process. The degree of relevance is based on the "possession of or access to resources for technology transfer or technology developments, and the actant's relationship with decision makers and sources of power" [8] (p. 7). Figure 3 illustrates the steps that were taken for conducting this research project.

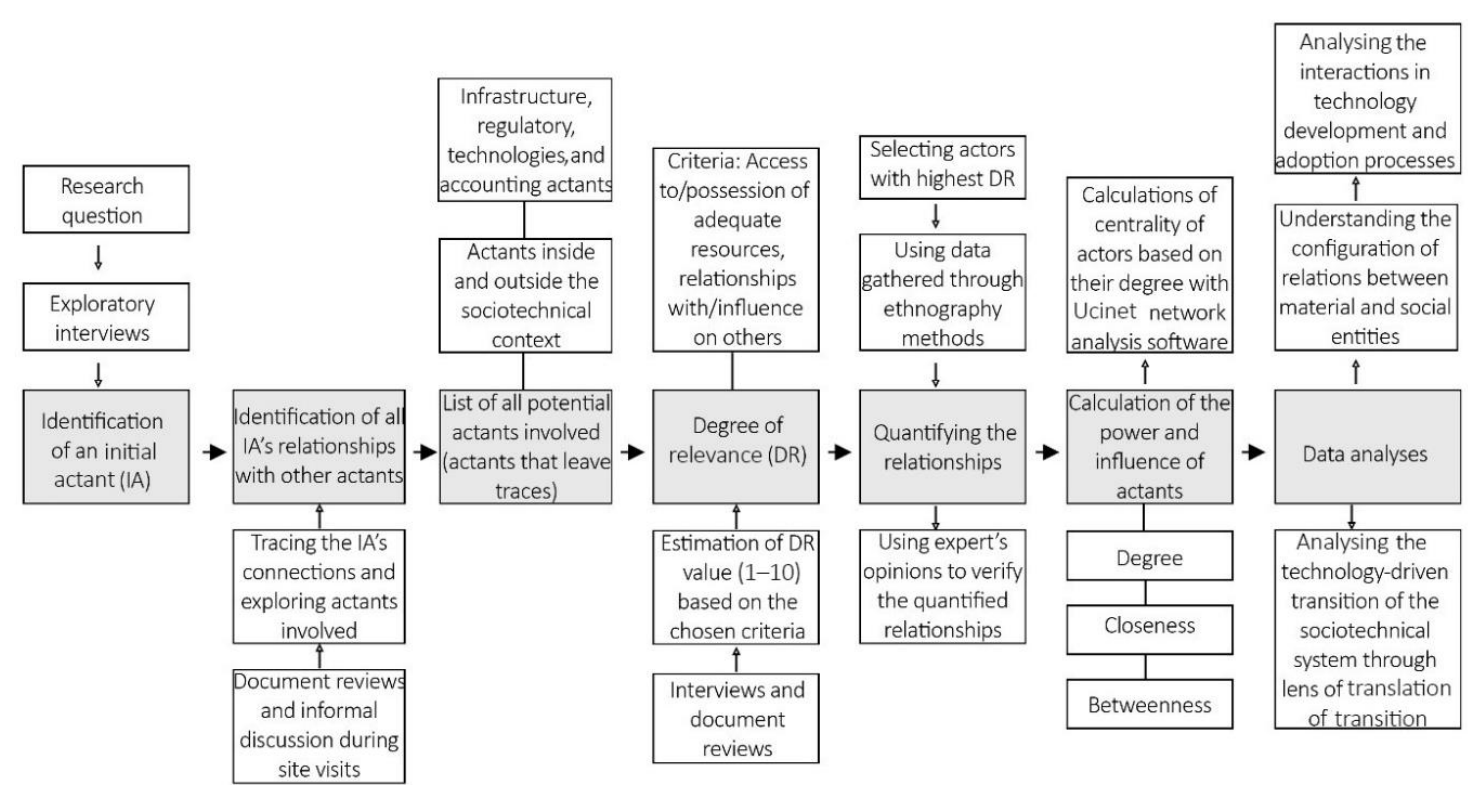

Figure 3. Methodological framework for the case study [8].

The agency of each actant in the configuration of interactions in the actor-network was measured by analyzing the relationships among actants involved in the transition process. For calculations 
and analyses of the actor-network, Ucinet software was used (Version 6.628, Analytic Technologies, Harvard, MA, USA). To measure the agency of actants, three indexes were used: (1) Degree of centrality, which indicates the number of ties or direct connections that each actant has with other actants; (2) Betweenness, an indicator that represents the actant's placement between other pairs of actants; and (3) Closeness, an index that represents the ability of an actor to reach other actants at short path lengths or an actant that is more reachable by other actants at short path lengths.

The calculation of the degree of centrality, betweenness, and closeness through Ucinet requires quantified data about the relationships of actants. To do so, we made a matrix table (Appendix A, Table A6) with the code name of all actants (Appendix A, Table A4). The relationship of each actant with all other actants was quantified through a three-point scale: $0=$ not connected, $2=$ indirect connection, and $4=$ connected. For verification of the scores that were given to the relationships of each actant with others, we asked the opinions of experts that were familiar with the transition process in Amsterdam as well as with the context and characteristics of technologies. These experts were niche developers (technology developers at Philips Growise center and Vegger) and researchers at Wageningen University and Research (WUR) [8]. The index of closeness represents the total distance of the actant from all other actors involved in transition process.

\section{Transition Trajectories in the Food-Production System of Amsterdam}

This section presents the results of the analyses of the development and adoption processes of alternative food-production systems in Amsterdam. These processes are explained through the three stages of disentanglement, punctualization, and re-entanglement.

\subsection{Disentanglement of the Existing Sociotechnical Regime of the Agricultural Sector}

The challenges of the agricultural sector and new technologies that have been developed in the Netherlands have destabilized the current sociotechnical regime of the agricultural sector and food systems. These challenges and pressures from niche, landscape and regime levels are explained in the following sections (Figure 4):

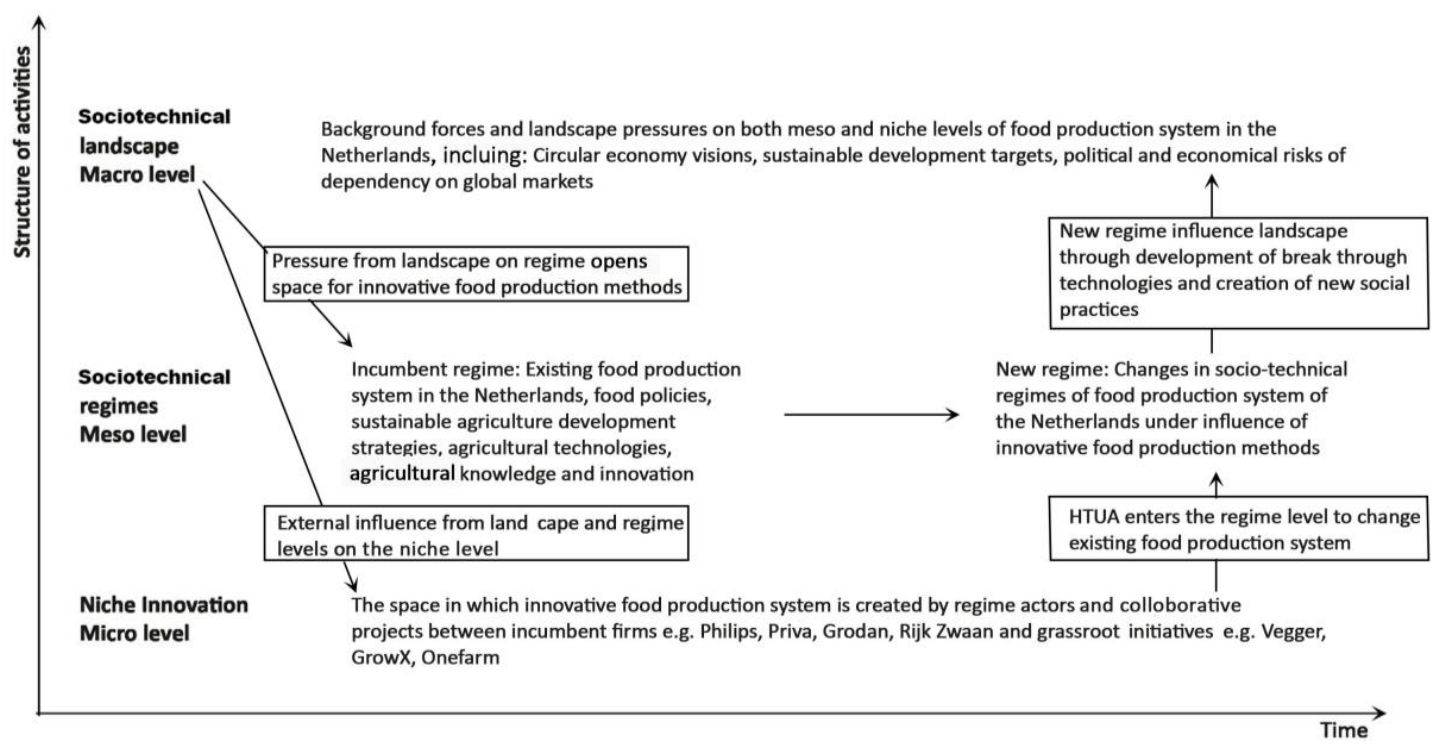

Figure 4. Instability in the sociotechnical regime of the Dutch agricultural sector through niche and landscape pressures.

\subsubsection{Landscape Pressures}

In the transition process of the Dutch agricultural sector, the landscape regime is highly affected by EU policies (i.e., the common agricultural policies, CAP). The EU policies are promoting more 
sustainable and circular agriculture among EU counties (interview AMS-08). The Dutch agricultural policies, which are affected by CAP, emphasize on the development of an innovative and sustainable agriculture (interview AMS-22). These policies have resulted in the development of so-called Dutch agricultural innovation and knowledge systems (AIKS). Development of AIKS has opened space for entrepreneurs that are seeking to find an innovative sustainable solution for the existing food system. The landscape pressures on the sociotechnical regime of food production in the Netherlands are associated with climate change and the unsustainability of industrial food-production systems. The threats of climate change to the Dutch agricultural sector have played an important role in the mobilization of forces from government, businesses and knowledge institutes in the Netherlands to create a more resilient food system (interview AMS-24). Moreover, the trends and market demand for healthy and local products are other crucial factors affecting the agricultural sector's transition, which have forced the government to support alternative food-production methods focused on environmental and social sustainability, health, and circularity. In the market-oriented agricultural sector of the Netherlands, the market trends play an important role in the emergence of alternative food production methods that are able to satisfy the market demands (interview AMS-02).

\subsubsection{Instability in the Regime}

Farmers, agricultural related businesses, local and national governments' policies for development of circular agriculture, Amsterdam's urban food strategy, agricultural technologies and knowledge, agricultural lands, greenhouses and start-ups (i.e., GrowX, Vegger and OneFarm) are main actants that shape the sociotechnical regimes of Dutch food systems (interview AMS-22). A lecturer at WUR mentioned that obesity and doubts about the quality and healthiness of agricultural products that are produced by the industrial food-production system have decreased public trust in industrial food production (interview AMS-24). According to one of the entrepreneurs active in the development of HTUA practices, the high cost of healthy food for producers and final consumers in addition to the inaccessibility of local products for all citizens have destabilized the current sociotechnical regime (interview AMS-06). The actants inside the sociotechnical regime that are active in the development of alternative urban food production systems are scientists from WUR and the Amsterdam Institute for Advanced Metropolitan Solutions (AMS Institute), local food producers in Amsterdam (i.e., conventional and high-tech urban agriculture practices), advocates of urban agriculture such as Food Council MRA and the Mediamatic foundation and start-ups who are attempting to convince the government to make healthy local food a greater priority (interview AMS-10). Alternative food production systems such as HTUA emerge to complement the existing system. Based on a professor at the Applied Science University of Amsterdam, the destabilization of existing food systems can be traced back to the industrialization of food system and urbanization in the Netherlands. They have changed the geography of food production and increased the gap between food and urban life. The value of urban land and focus on attracting entrepreneurs and businesses have become barriers for bringing the food production practices back to cities and closer to consumers (interview AMS-08).

\subsubsection{Niche Pressures}

In response to market demand from inside the Netherlands for more sustainable and healthy food and the interest of foreign markets in Dutch agricultural technologies, the private sector (including start-ups, small to medium enterprises, and huge tech companies) have developed technologies and initiatives to change the current food-production system (interview AMS-13). The availability of the required technology for the development of HTUA and the involvement of the private sector in niche development activities are other influential actors in the transition process (Figure 5). New practices are emerging through the creation of knowledge, developments in breakthrough technologies, and their application in urban and peri-urban areas (interview AMS-11). 

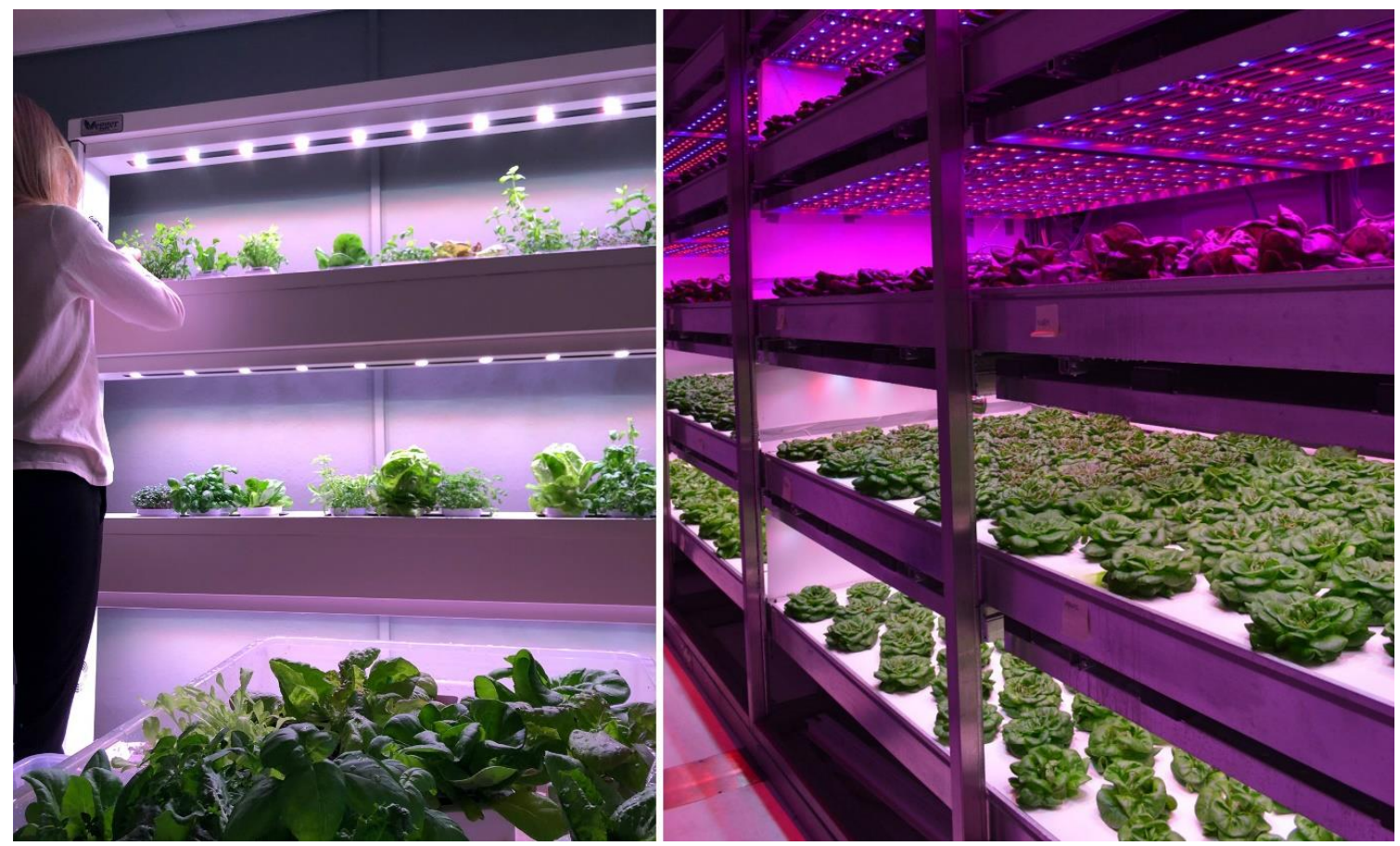

Figure 5. High-tech urban agriculture (HTUA) practices in the Netherlands. Left: Vegger indoor garden, Right: Philips Growise.

\subsection{Punctualisation of HTUA Practices in the Food-Production System of Amsterdam}

Increasing pressure from landscape actants such as new market demands for healthy and sustainable food, circular economy strategies, and foreign markets' interest in Dutch agricultural technologies, have destabilized the sociotechnical regime. Innovative food-production methods, such as indoor farming and vertical farming, have been created by start-ups and incumbent business in Amsterdam in order to enter the meso-level and change the incumbent socio-technical regime. Punctualization of new technologies for implementation in urban practices occurs in the second stage of technology-driven transitions. The following section analyzes and discusses the creation of new relations and configuration of interactions among actants involved in four moments of translation.

\subsubsection{Identification of Involved Actants in the Transition Process Towards HTUA}

In the Netherland's transition process from conventional agriculture to HTUA, the private sector plays a crucial role in developing technological novelties. Disentanglement of the existing regime has created possibilities for niche-level actors to introduce alternative solutions. The emergence of alternatives occurs simultaneously with the shaping of new actor-networks that are created through collaboration between niche developers and ex-alliances of the incumbent regime (i.e., agriculture-related businesses, knowledge institutes and local policy makers). In the Netherlands, relationships between niche-level and policy-making actors, political and technological regimes, society, research institutes, and universities, are the driving forces of transition. The transition of food-production practices is not planned centrally, and bottom-up forces play a critical role. However, the decentralized supervision of transition processes in Amsterdam by local and national governments has connected private and public sectors in the development of technologies and their adoption into urban practices. The involved actants include all entities within the agricultural knowledge and innovation system (AKIS), small and medium-sized enterprises (SMEs), start-ups, horticultural technologies, national and local policies, advocates of urban agriculture, various industries and non-governmental organizations (NGO). The identified human and non-human actants are shown in the Appendix A, Table A4. 
In this study, several influential actors from all levels of transition were studied. The focal actor was selected based on the betweenness centrality of actors. By tracing the associations and relationships between social and technological entities in the transition process, this study sought to measure the betweenness centrality of actants to identify the focal actant of the actor-network of transition (Appendix A, Table A5) The identification of actors and their relationships were measured through observational research and interviews with researchers, developers, policymakers, investors, and planners. Actants' relationships were rated as follows: $0=$ not connected, $2=$ indirect connection and $4=$ connected (Appendix A, Table A6).

The multiple centrality measures in the diagram and UCINET were analyzed as follows:

First, with respect to the degree of centrality (column 1), Philips, WUR, and urban farming initiatives have the greatest degree, which means they might be regarded as the most influential. The agency of these actants in the transition process is achieved through their access to other social and material entities, such as technologies, financial resources and infrastructures (Appendix A, Table A4). Philips, as a technology provider and product developer, has a direct relationship with many non-human actants. Its connections with non-humans have increased its centrality in the actor network. Second, regarding the betweenness centrality (column 8), SMEs, Philips, and High-tech indoor farming technologies are in a favored position to the degree that the actant is on the geodesic paths among other actants pairs in the network (Appendix A, Figure A1). To elaborate, other actants' dependency on these specific actants to make connections with others increases their power in the actor-network, which can be observed in the diagram. High betweenness centrality can be interpreted as control overflows; therefore, the private sector and advanced farming technologies can be regarded as the most influential nodes in terms of control overflows of regulations, connections, and immutable mobiles. Third, according to Freeman's definition, high values for closeness (column 6) indicate that a node is highly peripheral (IKEA, immigrants and the Royal House of the Netherlands), whereas low values indicate that a node is more central (Philips, technologies and urban food policies). The peripheral actors are more isolated than central nodes. Proximity is the extent to which an actor is close to the other actors within a given network. In other words, it is considered the sum inverse for the shortest distances between a given node and another within a network. Finally, eigenvector centrality (column 7) shows which nodes with high values are linked to nodes that are well-linked to other nodes in the network. It is often interpreted as popularity or status, and thus the actors with high eigenvector centrality have not only many connections, but also tie to many well-connected others. The scores show that the Ministry of Agriculture, Nature and Food Quality, Philips, and WUR are all linked to other nodes that are themselves well connected.

\subsubsection{Translation Process of Technological Novelties into Urban Food Production Practices in Amsterdam}

The results and interpretations of the actor-network are used to analyze the technology-driven transition trajectory in Amsterdam. The next sections explain the Punctualisation of transition through four moments of Translation.

\section{Problematisation}

Problematisation in the transition process of Amsterdam's agricultural sector involves many stakeholders. Disentanglement of the incumbent regime creates barriers for achieving goals for both the private sector and governmental organizations. The policy of the Dutch government for the agricultural sector is largely focused on sustainability. The Dutch government promotes bottom-up approaches to policy implementation. Governmental institutes organize collaborative projects between knowledge institutes and private businesses to develop multifunctional agriculture in peri-urban regions and within cities. The main strategies adopted by the Netherland's government for accelerating the sustainable agricultural sector development are:

- Supporting local and natural, organic agriculture;

- Promoting innovative low-energy agricultural practices; 
- Incentivizing business models for development of alternative food-production systems.

These strategies promote urban agriculture in built-up spaces, which are land efficient, and societal interest is their fundamental principle. They have provided opportunities for businesses and the private sector in order to get immersed in the transition problem of the agricultural sector. A private business can create a network of suppliers, consumers, and complementary stakeholders to develop new business plans for alternative food-production systems. The involvement of the private sector and businesses is supported by the Dutch golden triangle and Dutch Diamond Approach for sustainability developments. The Dutch golden triangle is referred to by the Ministry of Economic Affairs, Agriculture and Innovation as an example of the successful collaboration between agricultural research, industry and government. The Dutch Diamond Approach is based on the promotion of public-private partnerships for providing the private sector with easy access to funds, knowledge, and networks required for sustainability development goals. The main actors in the Dutch context for stimulation of innovation in the agro-food sector are knowledge institutes, the government, and private businesses (firms and farmers) (Figure 6).

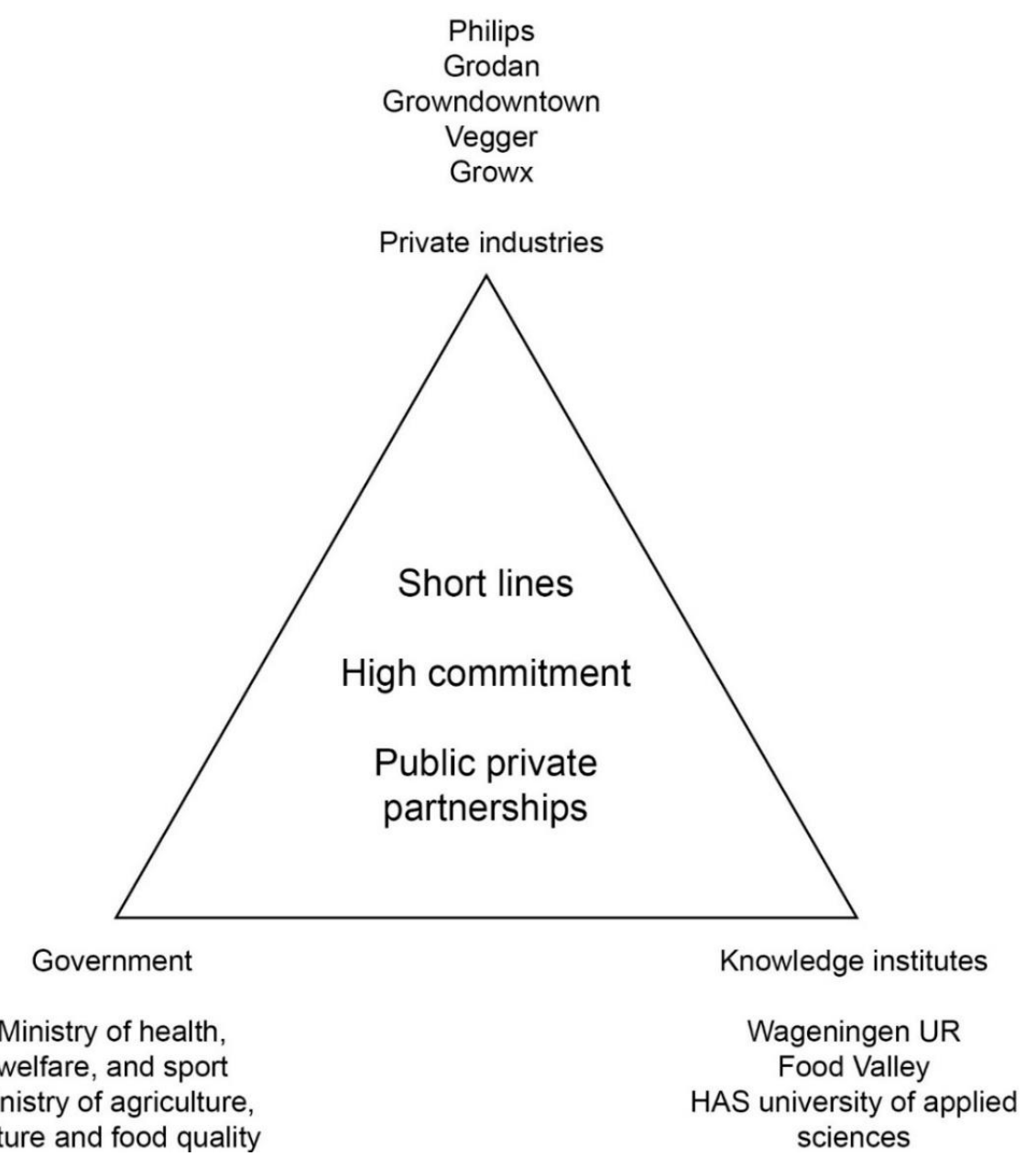

Figure 6. Dutch golden triangle in the development of HTUA.

The government plays a critical role in fund provision for agricultural innovation as well as R\&D projects. NWO, i.e., the Netherlands Organization for Scientific Research, is in charge of organizing $R \& D$ projects in various sectors and distributing public funds. In addition, RVO, i.e., the Netherlands Enterprise Agency, a sub-organization for the Economic Affairs Ministry, supports R\&D projects through allocating tax incentives for R\&D activities. 
Results of tracing actants and measuring the betweenness centrality in the actor-network of transition showed that the private sector and bottom-up initiatives play critical roles in the transition. The emphasis on bottom-up development in the Netherlands has given space to the private sector to lead the transition processes. Among the involved actants, Philips (a private company) had the highest centrality among actants. Most of the other entrepreneurs that are active in the transformation of urban food production practices in Amsterdam are connected to Philips. The high betweenness centrally of Philips allows it to play the role of focal actant in the transition of food production practices in Amsterdam. This position is owed to the technological advancements made by Philips in horticultural industries and the dependency of many Dutch initiatives on Philips' horticultural technologies for urban agriculture, vertical farming, and indoor farming practices. To create a network of relations that will support the transition Philips has attracted potential allies through introduction of technologies and solutions that could reduce landscape pressures and meet the market demands. To bring actors together and stabilize its own position, Philips defines its technologies and products as an obligatory passage point (OPP) for other actors involved. Philips' horticultural technologies have made both the government and private sector interested in HTUA and ensured the enrolment of technological entities in the actor-network of transition. The role of the OPP is to regulate the relationship between the regime, niche level, and landscape actors. The OPP attempts to configure the interplay between the three levels by increasing trust in novel technologies among actants of the incumbent regime. Philips, the focal actant, is responsible for entangling the actor-network of transition towards HTUA in Amsterdam as an alternative food-production method.

The presence of many private companies in the transition process towards HTUA in Amsterdam shows the importance of grass roots initiatives in the transition patterns of food-production practices. The bottom-up forces are created by private businesses such as Philips, Priva, and Rijk Zwaan, and start-ups such as Vegger, GrowX, and Onefarm. The role of these actants as stakeholders in technology development and application make their business strategies and plans influential in the transition process. The involvement of governmental organizations and knowledge institutes is through support and collaboration with the private sector. The main role of the government in the transition process is the top-down organization of bottom-up activities. The organization of bottom-up developments is done through development of AKIS, facilitating the cross-sectoral and Dutch Diamond approaches. Because of the crucial position of businesses in the transition process in the Netherlands, transition trajectories are highly affected by the emergence of new business ecosystems consisting of focal firms, their suppliers, complementor firms, and customers. In the case study of Amsterdam, Philips is the focal actant in terms of the overall transition and performs as the focal firm in creating new business environments. Philips is the main supplier of technologies (i.e., horticultural lighting) and owns patents for indoor farming technologies. It works with other stakeholders such as research institutes (i.e., WUR) and complementor firms (i.e., Priva, Rijk Zwaan and Grodan) to create new business ecosystems. Through providing the essential technologies, registration of patents, and creation of new business opportunities by opening a new market segment, Philips makes itself indispensable and its value proposition as is made an OPP in the transition process.

Philips, by introducing its horticultural LED lighting products (especially urban farming modules) as the OPP, attempts to reduce landscape pressure through developing alternative and climate change-resistant food-production methods. It works with niche-level actors to develop initiatives and business models with centrality of available technologies. Philips, as the focal actant, must create alliances between involved entities. To create a network of alliances and reduce resistance from the incumbent regime, Philips proposed its OPP as a promising solution to stabilize the sociotechnical regime. The potential entities were identified as those under pressure from landscape and niche levels, and therefore are interested in change. Each entity has predefined goals and obstacles to transformation. Philips ensures all entities' interests are met by the transition and that the OPP will be an effective method of removing their obstacles. Among the potential entities, the interest of political and policy regimes, the bottom-up development of sustainable agriculture, and the circular economy, 
will be met through collaboration between Philips, other private businesses, knowledge institutes and governmental organizations. Philips, as an actant within the technological regime, can offer its technologies to other complementor firms to develop new business ecosystems. The niche developers and users are considered potential stakeholders in these ecosystems (Appendix A, Figure A1).

\section{Interessement}

The identified entities in the transition to HTUA are consumers, incumbent firms, policy regime, and niche developers. In the interessement moment, Philips attempts to make the identified actants and entities interested in the transition to HTUA. The credibility of Philips and its technologies in the Dutch and global markets establishes the initial trust and facilitates creating alliances between social entities and niche developers. The role of Philips and its activities in HTUA development has attracted the interest of several SMEs and multinational companies, such as Grodan, Certhon, Priva, Rijk Zwaan, Enza Zaden and Agrolux to invest in business models related to HTUA. Furthermore, collaboration between the incumbent firms for creating a new business ecosystem facilitates the involvement of grass-roots initiatives and start-ups. These bottom-up approaches are highly supported by the government as well as the availability of technologies developed by Philips and its complementor firms in the market, thereby increasing the feasibility of HTUA practices. Start-ups in Amsterdam have easy access to the foreign market and their location increases their reliability in international markets. Policies are highly in favor of innovative start-ups and business models, and allow them to have access to national funds and subsidies for the development of their businesses.

The initial interessement device that was adopted by Philips for the transition to HTUA was the integration of knowledge and innovation development infrastructures in the Netherlands. To develop and implement agricultural innovations, general and specific knowledge in various fields such as Information and Communication Technologies (ICT), marketing, farming and biotechnology should be available. Economic actors and the society have a share in innovation culture. According to some of the researchers at WUR and AMS institute (interviews 9, 22 and 25) in the Netherlands, government policies, such as streamlining the regulations for performance of businesses; improving transparency; improving public services; allocating subsidies and tax incentives (e.g., the Research and Development Promotion Act); and facilitating access of innovation-oriented firms to financial resources first created an optimal environment and framework for innovation-oriented businesses. Second, it promoted public investment in the Dutch top sector's R\&D activities by closing the gap between businesses and knowledge institutes; facilitating the application of public research by business sectors; and promoting policy coordination and cooperation between innovation actants. However, the interviewees that were involved in HTUA practices (interviews 2, 3, 18 and 32) have pointed out that current regulations especially for food production and the creation of multifunctional buildings in urban areas are creating obstacles for development of their businesses.

Economic constraints are important obstacles in the technology-driven transition of urban food production systems. The high initial costs of HTUA practices and their low return of investment make it difficult to attract actants such as investors and the private sector. The Dutch top sector policy (topsectorenbeleid) plays an important role in removing these barriers. It promotes the cooperation between government, universities, and private businesses in public-private partnerships. Development of knowledge and innovation is the responsibility of the top consortium for knowledge and innovation (TKI) in each sector. The TKI facilitates collaboration between entrepreneurs and researchers to develop new products and services. This strategy ensures that public and private funds will contribute to $R \& D$ projects and initiatives that have positive social and environmental impact. Investment of the private sector in public-private partnerships can be in the form of direct financial contributions or allocation of working hours and facilities to the projects. To increase the flexibility in innovation developments, the proposals do not come directly from the Dutch government, but it encourages businesses and knowledge institutes to develop proposals for performance of R\&D projects for each sector. The top sector policy has been an effective method in the interessement moment of transition. The private 
sectors have been given the possibility to develop new products and services to perform in the business ecosystem created by Philips and its complementor firms.

In addition to technologies, the transition to HTUA is dependent on social entities. Philips, as an important technology development actor, has control over technological entities and can ensure their integration in the actor-network of transition. However, to ensure that the interest of social entities is integrated into the overall goals of the actor-network, it used the available knowledge and innovation development infrastructure in the Netherlands, including the agricultural innovation system, public-private partnerships, sector councils, and innovation networks. The AKIS had an influential role in connecting Philips with knowledge institutes such as WUR (interview AMS-17). Several collaborative research projects of Philips and WUR led to the improvement of vertical farming LED lights that are produced by Philips. The reputations of Philips and WUR were effective in increasing trust and interest in Philips.

\section{Enrolment}

A successful interessement moment can lead to enrolment. The enrolment moment in the transition process is one of the most problematic stages, because actants before enrolment tend to secure their interests in the actor-network. Therefore, the enrolment moment begins with additional interessement strategies by the focal actant. Philips' strategy for accelerating the enrolment of other actants in the actor-network of transition to HTUA helped to remove technological barriers, increase the energy efficiency of practices, and represent the value proposition of indoor farming and controlled environment techniques. The first step in the enrolment of identified actants is the creation of immutable mobiles. The immutable mobiles are technologies, products, and services that have been developed and tested by niche actors, and their functions, values, and identity are accepted by all other involved actants.

Therefore, enrolment of actants in the actor-network of transition requires standardized technologies that can be adopted in urban practices for local production of food. To create an immutable mobile that can be effective in the transition process, these technologies need to be accessible to other actants interested in the transition process. The accessibility of these technologies depends on their prices and the availability of knowledge to use with them. Philips' responsibility as the focal actant of transition is the development of eligible immutable mobiles. Philips' R\&D activities in developing horticultural technologies for transitioning to HTUA began in 1936 with research into the irradiation of plants with neon lights (Table 1). In 1993, Philips developed an artificial light recipe for growing plants indoors. The Philips light recipe was developed to indicate the lighting aspects; parameters that affect the light recipe such as weather conditions; and required techniques for reaching expected growth and productivity.

In 2000, Philips introduced its first grow light, Philips GreenPower, to the market. This generation of grow light was highly effective for growing plants but not efficient in terms of electricity consumption. In 2005, Philips introduced a more efficient light called the GreenVision. These first products were mostly focused on commercial green houses and were criticized by environmentalists because of their excessive electricity consumption. In 2007, to answer the critics, Philips formed its Horticulture LED solution team and for the first time began to hire agricultural scientists. The R\&D development projects conducted by this team resulted in the development of the first commercial project with multilayer growing systems. In addition to lighting systems, Philips has begun work on developing controlled environment technologies and vertical-farming equipment. Philips has registered numerous patents in the horticultural innovation and vertical farming sectors to secure its intellectual property in the HTUA market.

In 2010, the Philips GreenPower LED interlight and Philips GreenPower LED flowering lamp revolutionized the agricultural industry and engendered a more promising future for indoor and vertical farming. Philips' LED grow lights, compared with the earlier grow lights, were highly efficient and could reduce the electricity costs of indoor farming and increase the return on investment in this sector. The increasing return on investment in indoor faming has attracted the attention of many investors and governments. 
Table 1. Evolution of HTUA technologies by Philips.

\begin{tabular}{|c|c|c|c|}
\hline Year & R\&D Activities & Technologies & Involved Actants \\
\hline 1936 & $\begin{array}{l}\text { Initiation of research on irradiation } \\
\text { of plants }\end{array}$ & Neon lights & Philips \\
\hline 1993 & $\begin{array}{l}\text { Development of artificial light recipe } \\
\text { for growing plants indoor }\end{array}$ & Lighting system and recipe & Philips \\
\hline 2000 & Introduction of first grow light & Philips GreenPower & Philips \\
\hline 2005 & $\begin{array}{l}\text { Philips introduced a more energy } \\
\text { efficient light }\end{array}$ & GreenVision lights & Philips \\
\hline 2007 & $\begin{array}{c}\text { Formation of the Horticulture LED } \\
\text { solution team }\end{array}$ & $\begin{array}{l}\text { Controlled environment and } \\
\text { plantation technologies }\end{array}$ & $\begin{array}{l}\text { Philips, individual plants } \\
\text { scientists }\end{array}$ \\
\hline 2008 & First trial with GreenVision & Advanced GreenVision & Philips \\
\hline 2009 & $\begin{array}{l}\text { Development of first commercial } \\
\text { project with multi-layer growing } \\
\text { systems }\end{array}$ & $\begin{array}{l}\text { Vertical farming technologies } \\
\text { and hydroponics }\end{array}$ & Philips \\
\hline 2010 & $\begin{array}{l}\text { Development of first series of LED } \\
\text { grow lighting products }\end{array}$ & $\begin{array}{l}\text { GreenPower LED interlighting, } \\
\text { Philips GreenPower LED } \\
\text { flowering lamp }\end{array}$ & Philips \\
\hline 2011 & $\begin{array}{l}\text { Philips began to certify initiatives as } \\
\text { Horti Partners and signed a contract } \\
\text { with the IEDA protected horticulture } \\
\text { Co. Ltd. }\end{array}$ & Multi-layer indoor farms & $\begin{array}{l}\text { Philips, The IEDA protected } \\
\text { horticulture Co. Ltd., HTUA } \\
\text { investors and developers }\end{array}$ \\
\hline 2012 & $\begin{array}{c}\text { First commercial tomato grower } \\
\text { invested in Philips LED grow } \\
\text { solutions }\end{array}$ & Philips LED for tomatoes & $\begin{array}{l}\text { Philips, IEDA protected } \\
\text { horticulture Co. Ltd. }\end{array}$ \\
\hline 2013 & $\begin{array}{l}\text { Produced tomatoes with extra vitamin } \\
\text { C in association with WUR }\end{array}$ & GreenPower LED toplighting & Philips, WUR \\
\hline 2014 & $\begin{array}{c}\text { First commercial City Farm project in } \\
\text { US and Japan }\end{array}$ & $\begin{array}{l}\text { GreenPower LED interlighting, } \\
\text { Philips GreenPower LED } \\
\text { flowering lamp }\end{array}$ & $\begin{array}{l}\text { Philips, Urban agriculture } \\
\text { initiatives in Japan and US }\end{array}$ \\
\hline 2015 & Development of R\&D infrastructures & HTC7 facility & Philips \\
\hline 2017 & $\begin{array}{l}\text { Initiation of a business-to-business } \\
\text { strategy to expand its network and } \\
\text { support start-ups and initiatives }\end{array}$ & $\begin{array}{l}\text { GreenPower research modules, } \\
\text { GreenPower LED urban } \\
\text { farming modules }\end{array}$ & $\begin{array}{l}\text { Philips, Urban agriculture } \\
\text { initiatives, Horticulture } \\
\text { lighting businesses }\end{array}$ \\
\hline
\end{tabular}

In 2011, to create a network of alliances, Philips began to certify initiatives as Horti Partners. The Horti Partners were mostly urban or peri urban HTUA initiatives that were applying Philips LED grow lighting systems. Philips' advancements in horticultural technologies have attracted many foreign investors and developers. A Chinese company that works with Institute of Environment and Sustainable Development (IEDA) of China, Beijing IEDA Protected Horticulture, has signed an agreement with Philips to develop a HTUA project in China.

In 2012, the first commercial tomato grower invested in Philips LED grow solutions. The success of this tomato grower using LED grow systems improved the place of LED grow lighting in the market. Next, in 2013, Philips began its collaboration with research institutes and opened a joint research facility. In collaboration with WUR, Philips succeeded in producing tomatoes with extra vitamin C. By the end of 2013, Philips had tested its new GreenPower LED toplighting in 10 countries.

The first commercial project using Philips GreenPower LED toplighting and the first commercial City Farm project in the United States and Japan, respectively, were initiated in 2014. The achievements of Philips were presented at the High Wire event that year. After 2015, the HTC7 facility at the High Tech Campus in Eindhoven was opened with eight climate rooms, each with four growth layers; more than 540 production modules and 66,624 research modules have been replaced in the HTC7 facility, 97 light recipes for indoor farming were developed, and a global network of Philips Horticultural LED partners were created. In recent years, Philips' horticulture sector has been highly active and developed the urban farming GreenPower LED modules for application in HTUA projects. It initiated 
a business-to-business approach to expand its network. The horticultural technologies developed by Philips have become available for urban farming initiatives through Philips partners in Amsterdam and all over the world.

The development of horticultural LED lighting modules and light recipes through collaborative R\&D projects between Philips and WUR ensured the enrolment of technological novelties in the actor-network of transition towards HTUA. The technological novelties developed by Philips became accessible immutable mobiles in urban agricultural practices in Amsterdam. The LED lighting product, business ecosystem and light recipes have made these inventions accessible for niche developers.

In addition to creating a business ecosystem for indoor farming, Philips established the Grow Wise Center at the High-Tech Campus in Eindhoven. The Grow Wise Center is a research facility and permanent exhibition with a total growing surface of $234 \mathrm{~m}^{2}$. It was developed to attract investors and businesses to HTUA systems and technologies. Demonstration of the feasibility and efficiency of HTUA practices has been one of the influential interessement devices that were applied by the focal actants to enroll incumbent businesses and investors in the actor-network of transition towards HTUA.

\section{Mobilization}

The development of horticultural technology for HTUA has resulted in the enrolment of governmental institutions, as well as the involvement of academic institutes and social and technical entities, including incumbent firms in the agricultural sector and advocates of urban agriculture. The focal actant, Philips, after enrolment of the actants in the actor-network of transition towards HTUA, tried to keep all human and non-human actants interested and loyal to the actor-network. The mobilization strategies used by Philips were:

- Developing R\&D infrastructures in different cities of the Netherlands;

- Expanding the collaborative R\&D projects with academic institutes;

- Assigning the HTUA practices the role of spokesperson.

Although Philips started the R\&D of infrastructure for indoor farming in 1936, until 2009 its focus was on developing commercial greenhouses. However, after that, Philips allocated numerous resources to developing solutions for multifunctional vertical farms in urban areas and urban agriculture initiatives. Several R\&D centers and experimental projects were developed in collaboration with Philips Horti partners. The projects developed by Horti Partners in collaboration with Philips include the Staay Food Group's large-scale pilot project in Dronten, the largest vertical farm in Europe, and Brightbox in Venlo.

In addition to the development of R\&D infrastructure such as the Grow Wise center, Philips has expanded its collaboration with WUR. The expansion of these collaborative researches has resulted in the establishment of the Philips-WUR research center (Innovation and Demonstration Center LED in Bleiswijk) in 2013. Here, university scientists conduct research projects related to urban indoor farming, lighting recipes, and controlled environments. The scientists, working closely with Philips, can use Philips' R\&D infrastructure and pilot projects for their experimental research.

The latest policy of Philips to mobilize the forces was selecting an eligible spokesperson for the actor-network of transition to HTUA. This is the most crucial task of the focal actant in the mobilization moment. Philips chose a business-to-business strategy for distributing its technology among niche developers of HTUA and considered its certified Horti Partners as spokespersons for the actor-network. The Horti Partners are considered official business partners or experiment fields for Philips products. These partners are the initiatives that have applied Philips horticultural technologies into their practices. These practices focus on multifunctional urban indoor farming and have relationships with social entities. Therefore, they can be eligible representatives for both social and technological entities. 


\subsection{Re-Entanglement of HTUA in the Food System and Transition of the Incumbent Regime}

In the final stage of transition, re-entanglement, the actor-network of transition was shaped and the technological novelties for urban food production became diffused. The diffusion of technologies in urban practices started the transformation process of food production and supply in Amsterdam. These transformations tend to reduce the pressures from the socio-technical landscape and stabilize the incumbent sociotechnical regime through the creation of new relations among material and social entities and new practices. The transition trajectory is defined by the interplay of involved actants from various levels over time. Figure 7 illustrates the actants involved in the transition and their relationships.

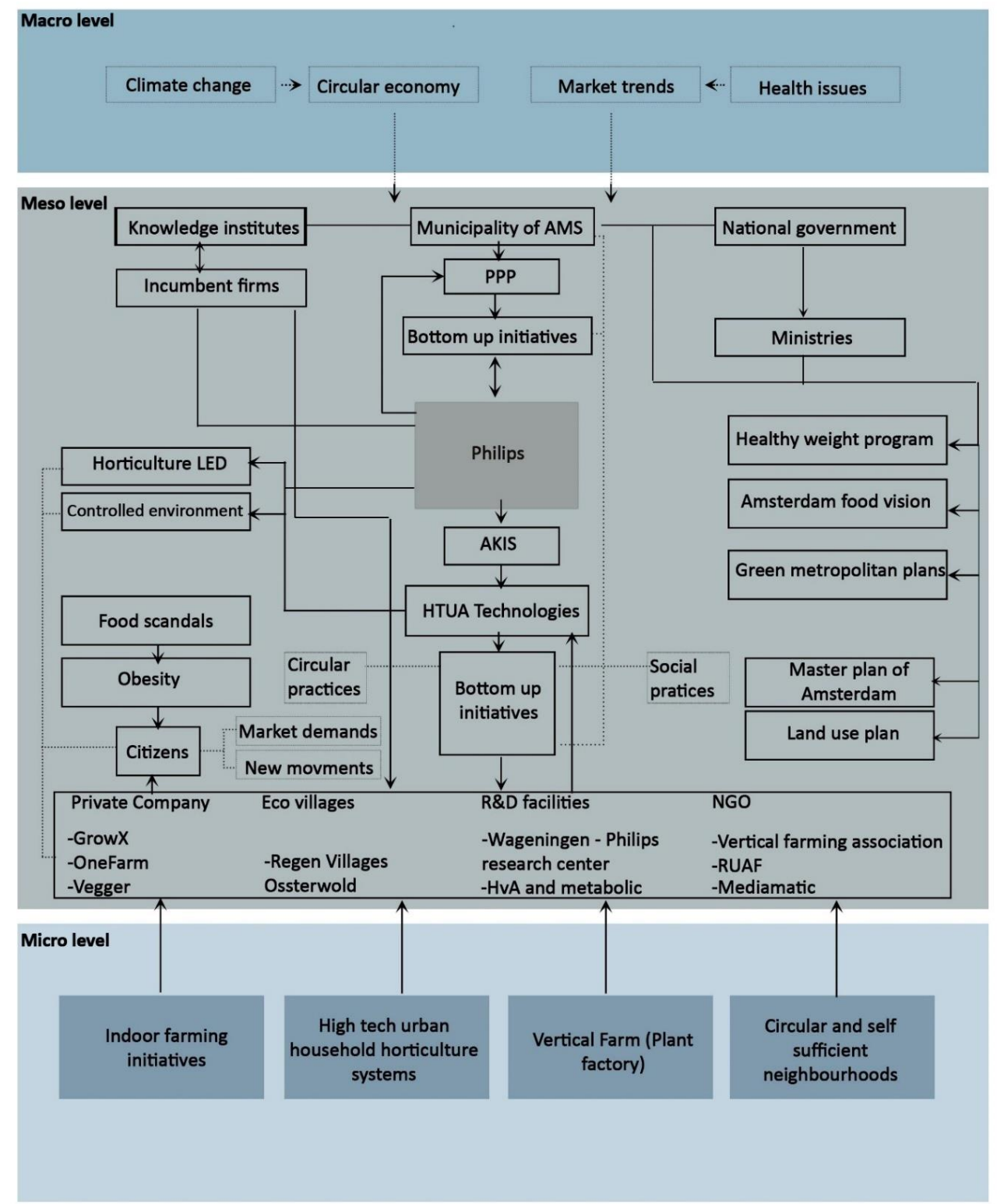

Figure 7. Actors of transition to HTUA in the multi-level perspective (MLP) levels.

The analysis of the developmental process of agricultural technologies and their integration in urban practices in Amsterdam provided an enhanced understanding of the importance of both social and technical entities and their role in a successful transition. Based on the results of the study, the involved actants, their roles in the development of HTUA technologies, and their practices are shown in the Appendix A, Table A7. 
Re-entanglement of a new actor-network in the sociotechnical regime occurred simultaneously with the formation of new urban practices, social practices, and urban systems. To entangle the niches in the sociotechnical regime, technological novelties must be integrated into urban spatial development plans and policies. They need to be understood by decision-makers and addressed in policies and development plans. By studying ongoing practices in Amsterdam, this study examined the re-entanglement process of new agricultural technologies into urban areas. The re-entanglement was performed by developing multifunctional urban food-production practices through grass-roots initiatives as well as new business cases with centrality of HTUA by incumbent firms. The development of HTUA practices in Amsterdam became feasible through the allocation of funds and investment by organizations such as the national green funds, the sustainability fund, and the Amsterdam Climate and Energy Fund (ACEF). Incumbent firms in the field of agricultural technology and equipment have developed business cases around HTUA. These businesses mainly focus on international markets such as China and the Middle East. Incumbent firms, such as RijkZwaam, Enza zaden, Grodan, Agrolux, Priva, and Philips, have made the Netherlands the main exporter of HTUA technologies worldwide. The new practices that have been developed by niche developers and incumbent firms to entangle HTUA in food production's socio-technical regime are summarized in Table 2.

Table 2. Niche development actors of transition to HTUA in Amsterdam.

\begin{tabular}{|c|c|c|c|}
\hline Type of HTUA & HTUA Project & Developer & Stakeholders \\
\hline $\begin{array}{l}\text { High-tech urban } \\
\text { household horticulture }\end{array}$ & Smart-indoor farm & Vegger & $\begin{array}{l}\text { Private, funded by private } \\
\text { sector }\end{array}$ \\
\hline $\begin{array}{l}\text { Multifunctional } \\
\text { indoor farms }\end{array}$ & Laboratory and educational services on HTUA & Onefarm & $\begin{array}{l}\text { Private, Funded indirectly by } \\
\text { government }\end{array}$ \\
\hline \multirow{4}{*}{$\begin{array}{l}\text { Vertical-farming } \\
\text { equipment }\end{array}$} & Vertical farming grow mediums & Grodan & Private, Private fund \\
\hline & Seeds for hydroponic and indoor cultivation & Rijk Zwaan & Private, Private fund \\
\hline & Lighting systems & Agarolux & Private, Private fund \\
\hline & Controlled environment & Certhon & Private, Private fund \\
\hline \multirow{4}{*}{ Research facilities } & Research on the feasibility of HTUA & $\begin{array}{l}\text { Wageningen university } \\
\text { and research }\end{array}$ & Public funded by government \\
\hline & $\begin{array}{l}\text { Research on urban food planning and } \\
\text { contribution of alternative food productions }\end{array}$ & $\begin{array}{l}\text { Amsterdam Institute for } \\
\text { Advanced Metropolitan } \\
\text { Solutions }\end{array}$ & $\begin{array}{l}\text { Public-private institute } \\
\text { funded by government }\end{array}$ \\
\hline & R\&D facilities and laboratory & Mediamatic & Nonprofit \\
\hline & R\&D facilities and laboratory & Metabolic foundation & Cultural institute \\
\hline \multirow{2}{*}{$\begin{array}{l}\text { Vertical farm } \\
\text { developers }\end{array}$} & Vertical farm for restaurant & Light4food & $\begin{array}{l}\text { Private, funded by } \\
\text { government and private sector }\end{array}$ \\
\hline & $\begin{array}{l}\text { Vertical indoor farm for nursing homes } \\
\text { and offices }\end{array}$ & Vegger & $\begin{array}{l}\text { Private, funded by private } \\
\text { sector }\end{array}$ \\
\hline \multirow{2}{*}{ Exhibitions } & $\begin{array}{l}\text { Exhibition and conference focused on Agri Food } \\
\text { Innovation and HTUA }\end{array}$ & $\begin{array}{l}\text { Vertical farming Expo } \\
\text { (Jakajima b.v.) }\end{array}$ & Private, Private fund \\
\hline & $\begin{array}{l}\text { Showcase and exhibition for professional in the } \\
\text { horticulture industry and HTUA }\end{array}$ & GreenTech Expo & Private, Governmental fund \\
\hline
\end{tabular}


Transfer to other Dutch Cities

The re-entanglement of HTUA in Amsterdam has resulted in the quick spread of these urban practices all over the Netherlands. Numerous initiatives were identified that are active in the field of HTUA, most of which are start-ups directly or indirectly subsidized by the government (Table 3).

Table 3. HTUA practices in the Netherlands.

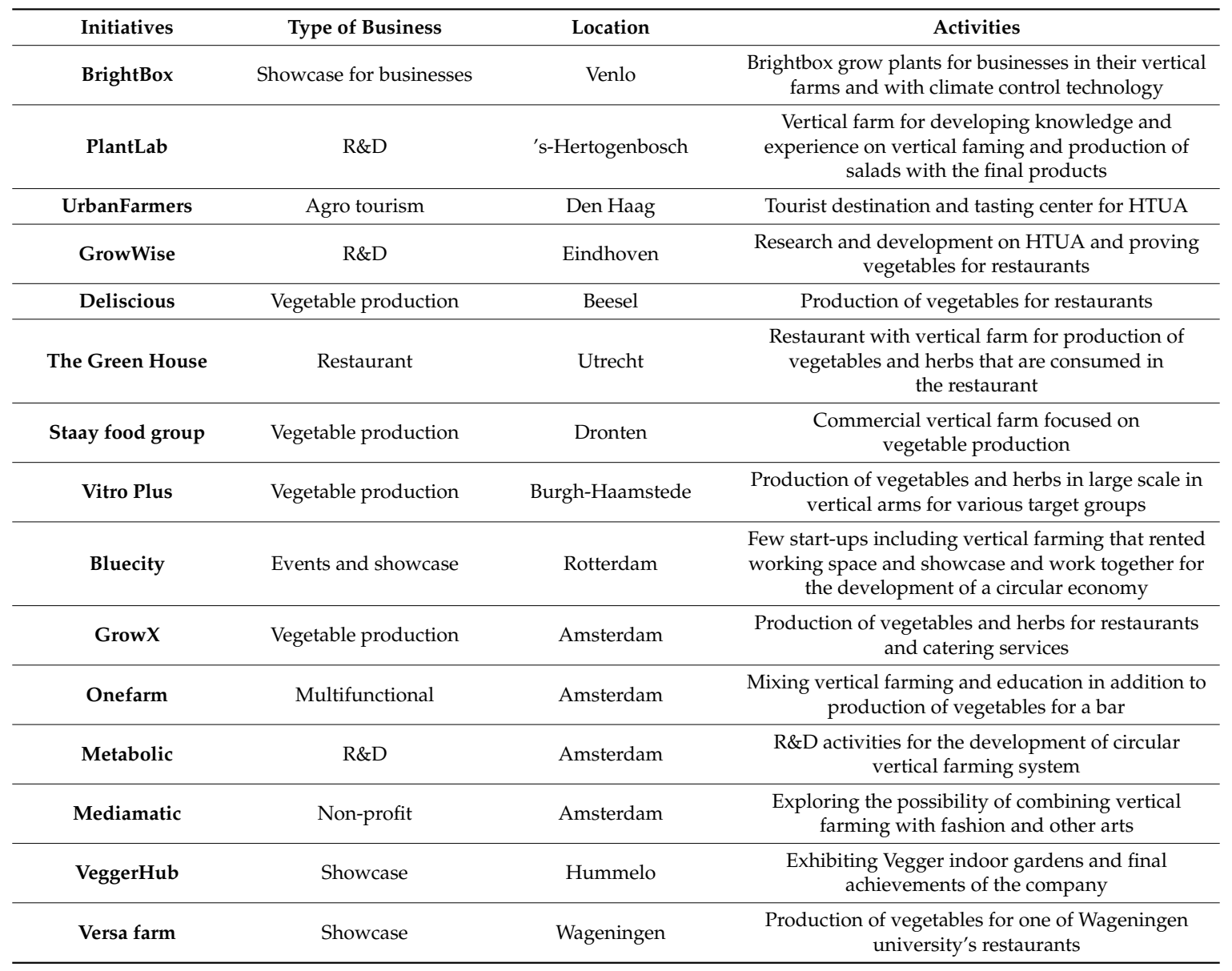

\section{Discussion}

This paper studied the sociotechnical transition of food production practices in Amsterdam. It studied the creation of the actor-network of transition by analyzing the roles of human and non-human actants. The empirical and theoretical findings of this research are discussed below.

\subsection{Empirical Findings}

The development of an efficient food production system has brought about food security for the Netherlands, but it has also created social and environmental challenges. The Dutch government has given priority to the development of sustainable alternative food-production practices. The Dutch government's emphasis on bottom-up approaches to policy implementation gave the opportunity to create a new business ecosystem, consisting of focal firms, complementary stakeholders, suppliers, and consumers. The business ecosystem created by Philips, the focal firm for indoor farming and HTUA practices, made many investors and businesses interested in developing business strategies for how to enter it. By involving incumbent firms and grass-roots initiatives, and via collaboration with government and knowledge institutes, Philips initiated the translation process for the creation of an actor-network of transition towards HTUA. By developing R\&D structures and introducing horticultural-LED lighting products, Philips has made other actors interested in the transition and 
has enrolled these potential actors in the network. To maintain the loyalty of the involved actants in the actor-network of transition, Philips placed its Horti Partners as spokespersons to represent the whole network and attract new alliances. The third phase was the development of novel technologies and their adaptation to urban practices through experimental projects. This phase led to the diffusion of technologies and the creation of several social practices in Amsterdam and other Dutch cities. The re-entanglement of HTUA as an alternative food-production method resulted in the creation of new businesses, fields of research in Dutch knowledge institutes and social practices.

The availability of advanced agricultural technologies in the Netherlands that are created through public-private partnerships has reduced the resistance from actants in the incumbent regime. As a result, niche developers were given the opportunity to introduce their technological novelties to actants within the incumbent regime of food production. The transition towards HTUA would not occur in the same way and pace without the involvement of Philips because it had a crucial role in the creation of the business environment of HTUA. However, Philips' role in the creation of an actor-network of transition is also dependent on other entities such as AKIS. The Dutch agricultural innovation and knowledge system - which is driven by bottom-up forces and collaboration between government, knowledge institutes, and businesses-has been an influential actants in the emergence of novelties. The technological novelties that have emerged through this process have shaped new relationships among incumbent firms, non-profit organizations, researchers, and start-ups in Amsterdam to work together for reshaping Amsterdam's food production system.

During the last decade, the technology giant Philips has led the development of horticultural technologies for adoption in HTUA practices. By applying novel agricultural technologies to urban food-production practices in Amsterdam, high-tech practices have found their place in the food system. Philips horticultural LED lights had a significant impact on reconfiguration of entities involved in food production practices in Amsterdam, and were the most influential non-human actant in the transition process. These impacts can be seen in the creation of new connections among other actants through their role in the development of the new business ecosystem, collaborations among businesses (e.g., Vegger, Priva, GrowX and Metabolic) and knowledge institutes (i.e., AMS institute, WUR and Amsterdam University of Applied Sciences), and changing the geography of food production by removing the barriers of food production in cities. One of the main barriers has been land scarcity and the high land value in Amsterdam. By providing the light that is needed for cultivation of plants inside existing buildings (i.e., houses, offices, restaurant and hotels), the horticultural LED lights have played an important role in bringing food production inside and on top of the buildings and changing the geography of food production in Amsterdam. The power and agency of Philips have allowed it to define its technologies (i.e., horticultural LEDs) as immutable mobile. Most of the initiatives in Amsterdam have adopted the Philips technologies in their practices. This has resulted in the standardization of high-tech urban agriculture initiatives. Although the standardization of practices has increased the familiarity and trust in HTUA, it has made the application of other niche technologies in HTUA practices and the business ecosystem more difficult. The creation of a business ecosystem around HTUA and the involvement of knowledge institutes and businesses in the niche development processes stand in contrast to the findings of Banerjee and Adenaeuer [24]. Their study identified "skepticism from business and academia" as a threat to such practices [24] (p. 51). They also mentioned that "The market opportunity is limited. It is feasible to grow only high value crops for consumers with dispensable money for such products" [24] (p. 51). The collaboration among businesses and knowledge institutes during past years has played a significant role in removing doubts about HTUA and to ensure their economic viability of these practices. However, this study confirms that the high initial costs of HTUA practices and the need for highly specialized workforces have increased the dependency of niche developers on public funds and subsidies. The importance of such funds has resulted in competition among businesses to receive national and European subsidies and funds. Although the transition process in Amsterdam is driven by bottom-up forces, the dependency of initiatives on national funds provides the national government with the possibility of aligning the goals of niche 
developers with its development objectives. Niche developers in Amsterdam focus on multifunctional HTUA with the centrality of social and environmental aspects of urban food production.

Overall, the results of this study show that the national and municipal policies and action plans were effective in the bottom-up development of HTUA through start-ups and private initiatives. The policies and plans offered the required infrastructure for the development of technological novelties. However, existing regulations (e.g., food production and multifunctional buildings) have created obstacles for the development of large-scale HTUA practices. The public-private partnership approaches and the agricultural innovation and knowledge system that connect knowledge institutes, business and the government have facilitated the application of technological novelties in experimental urban practices. The main aim of these approaches is to facilitate more technological development through initiatives with a global market orientation. This is in line with the findings of den Besten [25]. His research showed that "there is no direct need for vertical farming in The Netherlands, because of the country's history in high-tech horticulture" [25] (p. 310). He emphasized the economic values of education and applied research on HTUA, and pointed out that "the combination of green and technical knowledge and experience in this field, plus realistic business case calculations, may lead to vertical farms being a new export product next to high-tech greenhouses" [25] (p. 310). Our paper has identified the export of agricultural technologies and knowledge to other countries as an important goal for Dutch government and businesses, including Philips, and has confirmed the findings of den Besten [20].

The research shows that losses and gains in the translation process in Amsterdam are connected to the distribution of incentives. Policies define how public funds and subsidies are distributed between initiatives. In the Netherlands, the majority of national funds have been allocated to businesses with positive social and environmental impacts. Some of the main criteria for the investment in HTUA practices are the social and environmental impacts described in business plans. Low return on investments in HTUA practices makes start-ups and private-sector companies highly dependent on these funds. To gain access to national funds, most developers of HTUA practices define social cohesion, environmental sustainability, and circular economy as the core of their business cases. Consequently, technologies are adopted in multifunctional HTUA practices that pay more attention to the social and environmental impacts of practices than to productivity. Therefore, social and environmental values are the gains of technologies in the translation process, while the losses in the translation process are associated with downgrading the contribution of HTUA practices to the urban food system.

Concluding, the Dutch golden triangle and the public-private partnership improved the knowledge and innovation infrastructure and created a breeding ground for the development of new agricultural technologies and high-tech food production methods. A lesson for other countries might be to find similar approaches for public-private partnership, which can be beneficial for both the private and the public sector. Collaboration among knowledge institutes, private businesses, State-Owned Companies (SOCs) and governmental organizations can support the development of innovative technologies. Furthermore, the co-investment of the government in innovative projects can remove some of the financial obstacles for start-ups and motivate the private sector to become more innovative.

\subsection{Theoretical and Methodological Implications}

In this study the transition trajectories were defined as the way in which poorly connected individual actants become well-connected actants within an actor-network. We studied transition as a process in which networks of relationships are being shaped, and new sociotechnical assemblages in the regime level emerge. Networks are crucial in the transition processes and the agency of actants is critical in creating them. The relationships between human and non-human actants create sociotechnical systems of everyday practices. These relationships can be affected by the social, political, cultural, ecological and economic context. Different contexts can result in the creation of different practices of applying the same technologies in different places. ANT focuses on "descriptions of a very particular and foundational activity: the assembling, disassembling, and reassembling of associations" [26] 
(p. 336). However, in the methodological approaches of ANT, the impact of social, political and cultural contexts is not emphasized [27,28]. In this study we analyzed the relevance of context in the transition process and studied the impact of context on the agency of each actant. It showed that the influence of context on actants affects the sociotechnical assemblages that are shaped through their connections.

Applying the principles of ANT as introduced in this paper shifts the focus of technology-driven transition toward the connections in a network. Instead of the spatial dimension, the geography and the scale of transition, the creation of new connections was investigated. Faik et al. [17] indicate that in ANT studies, where there is a new connection, the network is expanded in that dimension [17]. Instead of geography and space in the transition process, ANT looks at the network, connections and creation of associations [29]. Novelties can cut the distances and disturb geographical proximity. In this way technological novelties can result in new associations and relations. For instance, horticultural LED lighting and controlled environment systems can change the relationships between cities, built-up spaces and agriculture.

In ANT's conceptual framework, each actant is a node or a network at the same time. The networks in a sociotechnical regime are not bigger than the other ones, but they can be longer or more intensively connected $[30,31]$. In the technology-driven transition pattern the developments within the top-down and bottom-up transition processes depend on how the individual actants involved in the processes become collectives (i.e., assemblages or actor-networks). The outcomes of these processes rely on individuals' actions that result in collective actions.

Technological novelties are the focus of technology-driven transition studies [8,31]. Analyzing the effect of future technologies on socio-technical systems can be beneficial in the evaluation of long-tern plans in decision-making processes [32]. Applying technology forecasting approaches can help to gain a better understanding of yet-to appear technologies and providing recommendations for planners and decision makers about the future possibilities [33]. Novelties and yet-to-appear material entities can change the way actants are interacting in the present. The impact on the configuration of relations among other actors can define the beingness of an entity. Therefore, yet-to-appear material entities can be assigned beingness. The plan to make self-sufficient neighborhoods that produce their own food and energy was introduced a few years ago in Amsterdam. Private businesses claimed they were able to build these neighborhoods of the future through the application of technologies that are being developed by companies such as Philips. Based on their plans and concepts of yet-to-appear material entities (e.g., self-sufficient houses), many Dutch families invested in the project, debates were conducted around the feasibility of these concepts and other businesses and planners and architects tried to develop similar concepts. Although these neighborhoods do not exist yet, they have affected the interactions among other actors that are involved in the transition of urban food production practices in Amsterdam. The findings of this study showed that technology-driven transition is not only dependent on the potential of existing technological novelties for cities but also on the yet-to-appear material entities that are in the development process.

The results also showed some limitations of the current proposed framework. One of the challenges in applying the framework was to accurately quantify the relationships between actants in a complex stakeholder field. Future studies on technology-driven transition might adopt mixed qualitative and quantitative approaches to improve the accuracy and reliability in quantifying the relationships and calculating the betweenness centrality of involved actants. Marsden [34] suggests that surveys are useful tools for studying the connection between actors and argues that they are a vital source of network data. Quiédeville et al. [35] used surveys in an ANT study to analyze the user's role in the transition process toward organic agriculture. These examples show that application of quantitative research methods, such as surveys, in transition studies can be helpful to collect more accurate data for rating the relationships between involved actants. Such data may also provide different perspectives on these relationships. 


\section{Conclusions}

This paper proposed a conceptual framework for studying technology-driven transitions. The framework conceptualizes the transition trajectories as a process in which niche developers expand their network and diffuse their innovations through the re-configuration of the relationships between the entities involved in the socio-technical system. The framework was effective in understanding the interactions among actants and their agency in the transformation of the Amsterdam food production system. By applying this framework, we were able to identify the role of new technologies in destabilizing the incumbent sociotechnical system and the role of the emerging business ecosystems in decreasing the resistance to change and path dependency. The framework can be useful for other studies to analyze the transition trajectories toward alternative systems. However, the system users and their demands can have an influential role in the transformation of urban systems and the emergence of system alternatives [36,37]. Further studies are needed to analyze their agency in technology-driven transitions in different contexts.

The case in Amsterdam showed that technology development, and its adaptation and adoption in urban food production practices can be supported by business-to-business collaboration, collaborative research projects and public-private partnerships. In Amsterdam, the novel technologies were adopted by start-up initiatives. Their role in the transition process was defined by incumbent businesses such as Philips that provided essential technologies for these practices, and governmental organizations that provided incentives for businesses that contributed to a circular economy and climate-change adaptation. The dependency of these resources encouraged the niche developers to prioritize the social and environmental impacts of their practices. The introduction of HTUA practices in Amsterdam, as innovative products and services, integrated new agricultural technologies into urban lifestyles and shaped new types of agricultural businesses. Consequently, the business models of niche developers, especially the value propositions and missions, were an effective intermediary among the actants involved in the local diffusion of technological novelties in the urban food production system.

However, to evaluate the social, economic and environmental sustainability of technology-driven transition, a more large-scale application of promising novelties (i.e., HTUA) is required. The municipal governments in the Netherlands could play a more active role in organizing large-scale experimental projects in cities, by bringing leading entrepreneurs, researchers and end-users together to evaluate the economic viability as well as the environmental and social impacts of these alternative urban systems. Currently, the experimental projects that are supported by public-private partnership programs receive partial funding for developing high-risk businesses models, which are carried out by two or more small- or medium-sized enterprises. Involving municipal governments in large-scale pilot projects could increase the effectiveness of experimental projects, through the allocation of spaces for the niche developers, facilitating access to the market and attracting companies and research institutes to get involved in the different phases of the project.

Author Contributions: Conceptualization, M.H.F.; methodology, M.H.F.; software, M.H.F.; validation, M.H.F. and M.E.T.; formal analysis, M.H.F.; investigation, M.H.F.; data curation, M.H.F., G.J.C.; writing-original draft preparation, M.H.F. and G.J.C.; writing, M.H.F. and G.J.C.; visualization, M.H.F.; supervision, M.E.T., A.v.d.V., and G.J.C. All authors have read and agreed to the published version of the manuscript.

Funding: This research received no external funding.

Conflicts of Interest: The authors declare no conflict of interest. 


\section{Appendix A}

Table A1. Policy documents, action plans and programs.

\begin{tabular}{|c|c|}
\hline & Amsterdam \\
\hline \multirow{8}{*}{$\begin{array}{l}\text { Policy documents } \\
\text { and agendas }\end{array}$} & Milan food policy pact \\
\hline & Peri Urban Regions Platform Europe \\
\hline & City deals \\
\hline & Sustainable Food policy document by The Ministry of Agriculture, Nature and Food Quality \\
\hline & Sustainable Development Goals 2030 of Nations High-Level Political Forum \\
\hline & $\begin{array}{l}\text { Policy Document on Sustainable Food } \\
\text { Towards sustainable production and consumption of food }\end{array}$ \\
\hline & Dutch policy document on sustainable crop protection \\
\hline & $\begin{array}{l}\text { Sustainable Amsterdam } \\
\text { Agenda for renewable energy, clear air, a circular economy and a climate-resilient city }\end{array}$ \\
\hline \multirow{10}{*}{$\begin{array}{l}\text { Action plans and } \\
\text { programs }\end{array}$} & Proeftuin Amsterdam \\
\hline & Healthy weigh program \\
\hline & Amsterdam green metropolitan plan \\
\hline & Towards circular economy \\
\hline & Amsterdam food strategy \\
\hline & Public-private partnership (PPP) programs \\
\hline & Dutch action plan on sustainable plant protection \\
\hline & National plan sustainable crop protection \\
\hline & $\begin{array}{l}\text { Action plan to establish } \\
\text { a free zone for sustainability } \\
\text { and circular economy }\end{array}$ \\
\hline & Program for Circular Economy in the Netherlands by 2050 \\
\hline
\end{tabular}

Table A2. Semi-structured interviews and informal discussions. Case study of Amsterdam.

\begin{tabular}{|c|c|c|c|c|}
\hline Interviewee & Position & Affiliation & Location & Date \\
\hline AMS-01 & Director & $\begin{array}{c}\text { Non-profit organization, } \\
\text { Mediamatic }\end{array}$ & $\begin{array}{l}\text { Amsterdam-Informal } \\
\text { discussion }\end{array}$ & Jun. 2016 \\
\hline AMS-02 & Founder & $\begin{array}{c}\text { Non-profit organization, } \\
\text { Mediamatic }\end{array}$ & Amsterdam & Jun. 2016 \\
\hline AMS-03 & Founder & Start-up Vegger & Hummelo & Feb. 2017 \\
\hline AMS-04 & Director & Fundraising, Brands B.V. & $\begin{array}{l}\text { Hummelo-informal } \\
\text { discussion }\end{array}$ & Apr. 2018 \\
\hline AMS-05 & Founder & Start up, Grow X & Amsterdam & Mar. 2017 \\
\hline AMS-06 & Founder/Investor & Flax enterprise B.V. & Hummelo & Mar. 2017 \\
\hline AMS-07 & Coach & PakAn & Hummelo & Feb. 2018 \\
\hline AMS-08 & Researcher, professor & $\begin{array}{l}\text { Applied science university of } \\
\text { Amsterdam }\end{array}$ & Amsterdam & Apr. 2017 \\
\hline AMS-09 & professor & AMS institute & Amsterdam & Jan. 2018 \\
\hline AMS-10 & Coordinator & $\begin{array}{l}\text { Landschapstriënnale, The next } \\
\text { landscape }\end{array}$ & Nieuw-Vennep & Sep. 2017 \\
\hline AMS-11 & Plant Specialist & $\begin{array}{l}\text { Philips Horticulture LED } \\
\text { Solutions GrowWise Center }\end{array}$ & Eindhoven & Oct. 2017 \\
\hline AMS-12 & $\begin{array}{l}\text { Finance officer for } \\
\text { startups }\end{array}$ & Startlife, Rabobank & $\begin{array}{l}\text { Wageningen—informal } \\
\text { discussion }\end{array}$ & Apr. 2017 \\
\hline AMS-13 & Project manager & Agro-food Oost NL & $\begin{array}{l}\text { Apeldoorn—informal } \\
\text { discussion }\end{array}$ & Mar. 2017 \\
\hline AMS-14 & $\begin{array}{l}\text { Senior Advisor Food } \\
\text { valley }\end{array}$ & StartLife & Wageningen & Apr. 2017 \\
\hline
\end{tabular}


Table A2. Cont.

\begin{tabular}{|c|c|c|c|c|}
\hline Interviewee & Position & Affiliation & Location & Date \\
\hline AMS-15 & Business developer & $\begin{array}{l}\text { Promens, agro products } \\
\text { manufacturer }\end{array}$ & $\begin{array}{l}\text { Zevenaar-informal } \\
\text { discussion }\end{array}$ & May. 2017 \\
\hline AMS-16 & Founder & Bluecity & Rotterdam & May. 2017 \\
\hline AMS-17 & Advisor & $\begin{array}{l}\text { Amsterdam spatial planning } \\
\text { council }\end{array}$ & Amsterdam & Apr. 2017 \\
\hline AMS-18 & Financial officer & GrowX & $\begin{array}{l}\text { Amsterdam-informal } \\
\text { discussion }\end{array}$ & Mar. 2017 \\
\hline AMS-19 & Manager & ifund & $\begin{array}{l}\text { Rotterdam-informal } \\
\text { discussion }\end{array}$ & May. 2017 \\
\hline AMS-20 & Location manager & Innoforte & $\begin{array}{l}\text { Velp-informal } \\
\text { discussion }\end{array}$ & Apr. 2018 \\
\hline AMS-21 & $\begin{array}{l}\text { New market } \\
\text { developer }\end{array}$ & Nationaal Groenfonds & $\begin{array}{l}\text { Amersfoort-informal } \\
\text { discussion }\end{array}$ & Apr. 2017 \\
\hline AMS-22 & University professor & Wageningen UR & Wageningen & Jan. 2018 \\
\hline AMS-23 & Head of chair group & Wageningen UR & Wageningen & Dec. 2017 \\
\hline AMS-24 & $\begin{array}{l}\text { Economic researcher } \\
\text { on vertical farming }\end{array}$ & Wageningen UR & $\begin{array}{l}\text { Webinar-Informal } \\
\text { discussion }\end{array}$ & Nov. 2017 \\
\hline AMS-25 & University professor & Wageningen UR & $\begin{array}{l}\text { Ede- Congress- } \\
\text { informal discussion }\end{array}$ & Mar. 2018 \\
\hline AMS-26 & $\begin{array}{l}\text { Food innovation } \\
\text { advisor }\end{array}$ & Ondernemer lift+, & $\begin{array}{l}\text { 's-Hertogenbosch- } \\
\text { informal discussion }\end{array}$ & Sep. 2017 \\
\hline AMS-27 & $\begin{array}{l}\text { Project leader and } \\
\text { Agri Business } \\
\text { Development }\end{array}$ & Ondernemer lift+, & 's-Hertogenbosch & Sep. 2017 \\
\hline AMS-28 & Co-founder & Pieterpikzonen B.V. & $\begin{array}{l}\text { Luinjeberd-informal } \\
\text { discussion }\end{array}$ & Aug. 2017 \\
\hline AMS-29 & Director & Tuin plus & Luinjeberd & Aug. 2017 \\
\hline AMS-30 & Location Manager & Eurest Schiphol & Amsterdam & Feb 2017 \\
\hline AMS-31 & Researcher & Wageningen UR & Wageningen & Feb. 2018 \\
\hline AMS-32 & Founder & ReGen villages & Online & Jan. 2018 \\
\hline AMS-33 & Co-Founder & Food council MRA & Amsterdam & Jan. 2018 \\
\hline
\end{tabular}

Table A3. Events, meetings and research and development collaborations in the course of data collection in Shanghai and Amsterdam.

\begin{tabular}{|c|c|}
\hline & Amsterdam \\
\hline \multirow{4}{*}{ Site visits } & Grow wise center \\
\hline & Veggerhub indoor vertical farms \\
\hline & Growx vertical farm \\
\hline & Bluecity \\
\hline \multirow{4}{*}{ Events } & EDE world food center-food and cities \\
\hline & Green Anpakers \\
\hline & Next landscape summer school \\
\hline & Opening of Amsterdam Food council \\
\hline \multirow{5}{*}{ Meetings } & Start life \\
\hline & ANFP meetings-AMS' Network for Food Planning \\
\hline & AESOP food planners peer group \\
\hline & Groenfonds \\
\hline & Op oost \\
\hline \multirow{2}{*}{$\begin{array}{c}\mathrm{R} \& \mathrm{D} \\
\text { collaborations }\end{array}$} & Vegger \\
\hline & Innofotre, health care center \\
\hline
\end{tabular}


Table A4. Influential actants in transition towards HTUA in Amsterdam.

\begin{tabular}{|c|c|c|c|c|}
\hline Categories & Actant & Abbreviation & Main Role & $\overline{D R}$ \\
\hline \multirow{37}{*}{$\begin{array}{l}\text { Humans and } \\
\text { associations }\end{array}$} & Philips & PHS & Product development & 9 \\
\hline & Grodan & GRN & Product development & 7 \\
\hline & Rijk Zwaan & RZ & Agricultural products & 8 \\
\hline & Enza Zaden & $\mathrm{EZ}$ & Agricultural products & 7 \\
\hline & Certhon & CR & Product development & 7 \\
\hline & Agrolux & ALX & Product development & 6 \\
\hline & RAUF & RAUF & Knowledge institute & 7 \\
\hline & FAO & FAO & International organization & 7 \\
\hline & Metro Group & MTO & Product development & 6 \\
\hline & IKEA & IKEA & Product development & 8 \\
\hline & Wageningen university & WUR & Knowledge institute & 8 \\
\hline & Initiatives/ Start-ups & ISU & Urban practice developers & 8 \\
\hline & Urban food council & UFC & Platform & 7 \\
\hline & $\begin{array}{l}\text { Amsterdam Institute for Advanced } \\
\text { Metropolitan Solutions }\end{array}$ & AMS & Knowledge institute & 6 \\
\hline & $\begin{array}{l}\text { University of applied sciences of } \\
\text { Amsterdam }\end{array}$ & HVA & Knowledge institute & 7 \\
\hline & Mediamatic & MM & Research \& Development & 6 \\
\hline & Metabolic & MB & Research \& Development & 6 \\
\hline & Farmers & FS & Producer & 6 \\
\hline & Municipality & MUN & $\begin{array}{l}\text { Formulation and } \\
\text { implementation of policies }\end{array}$ & 7 \\
\hline & Consumers of products & $\mathrm{CON}$ & Consumers, Target group & 8 \\
\hline & Tourists & TUR & Consumers, Target group & 6 \\
\hline & Schiphol airport & SA & $\begin{array}{l}\text { Clients of technological and } \\
\text { agricultural products }\end{array}$ & 6 \\
\hline & Users of systems & US & $\begin{array}{l}\text { Clients of technological } \\
\text { products }\end{array}$ & 6 \\
\hline & Ministry of Health, Welfare and Sport & VWS & Regulation and assessments & 6 \\
\hline & $\begin{array}{c}\text { Ministry of Agriculture, Nature and } \\
\text { Food Quality }\end{array}$ & LNV & Supporting niche developers & 7 \\
\hline & National green funds & NGF & Investor & 8 \\
\hline & Growx & GX & Producer of vegetables & 7 \\
\hline & Vegger & VEG & Product developer & 7 \\
\hline & Grown downtown & GDT & Producer of vegetables & 6 \\
\hline & Mayor & MAY & $\begin{array}{l}\text { Implementation of policies } \\
\text { and decision maker }\end{array}$ & 6 \\
\hline & Researchers & PRR & $\begin{array}{l}\text { Advocate of alternative } \\
\text { food-production methods }\end{array}$ & 8 \\
\hline & Architects & $\mathrm{ARCH}$ & $\begin{array}{l}\text { Advocate of alternative } \\
\text { food-production methods }\end{array}$ & 8 \\
\hline & Urban planners & UP & $\begin{array}{l}\text { Advocate of alternative } \\
\text { food-production methods }\end{array}$ & 8 \\
\hline & Agricultural scientists & AS & $\begin{array}{l}\text { Advocate of alternative } \\
\text { food-production methods }\end{array}$ & 8 \\
\hline & OOST NV & OST & $\begin{array}{l}\text { Coaching services for } \\
\text { initiatives }\end{array}$ & 7 \\
\hline & Environmentalist & ENV & $\begin{array}{l}\text { Advocates of sustainable } \\
\text { food-production methods }\end{array}$ & 6 \\
\hline & Retailers & RET & Provider of products & 6 \\
\hline
\end{tabular}


Table A4. Cont.

\begin{tabular}{|c|c|c|c|c|}
\hline Categories & Actant & Abbreviation & Main Role & DR \\
\hline \multirow{22}{*}{$\begin{array}{l}\text { Humans and } \\
\text { associations }\end{array}$} & Food and beverage companies & FBC & $\begin{array}{l}\text { Provider and developers of } \\
\text { products }\end{array}$ & 6 \\
\hline & National government & NG & $\begin{array}{l}\text { Supporting initiatives through } \\
\text { public-private partnership }\end{array}$ & 8 \\
\hline & Farmers consultants & FC & Coaching services & 6 \\
\hline & Start-ups consultants & SC & $\begin{array}{l}\text { Coaching services for } \\
\text { initiatives }\end{array}$ & 7 \\
\hline & Manufacturers & MAN & Producers & 6 \\
\hline & Van Amsterdam Boedem & VAB & Platform for initiatives & 7 \\
\hline & Kickoff starter & KS & Fund raising & 6 \\
\hline & Startlife & SL & $\begin{array}{l}\text { Coaching services for } \\
\text { initiatives }\end{array}$ & 7 \\
\hline & Parliament & PAR & Policy formulation & 6 \\
\hline & Food valley & FV & Platform & 7 \\
\hline & City council & $\mathrm{CC}$ & Policy formulation & 7 \\
\hline & Rabobank & RABO & Funder & 7 \\
\hline & Immigrants & IMM & $\begin{array}{l}\text { Target group of some } \\
\text { developers }\end{array}$ & 6 \\
\hline & HAS University of Applied Science & HAS & Knowledge institute & 6 \\
\hline & King & KNG & $\begin{array}{l}\text { Advocate of alternative } \\
\text { food-production methods }\end{array}$ & 7 \\
\hline & Minster & MIN & Decision maker & 6 \\
\hline & Provincial states & PRS & Policy formulation & 6 \\
\hline & Labor & LBR & Providing services & 6 \\
\hline & $\begin{array}{l}\text { Ministry of Education, Culture and } \\
\text { Science }\end{array}$ & OCW & Policy formulation & 6 \\
\hline & NGOs & NGO & Supporting initiatives & 7 \\
\hline & Non-profit organizations & NPO & Supporting initiatives & 6 \\
\hline & BlueCity & $\mathrm{BC}$ & Platform & 7 \\
\hline \multirow{7}{*}{$\begin{array}{l}\text { Representatives } \\
\text { of nature }\end{array}$} & Vegetables and herbs & $\mathrm{VH}$ & Pressure on regime & 8 \\
\hline & Climate change & $\mathrm{CC}$ & Pressure on regime & 8 \\
\hline & Weather conditions & WEA & Pressure on regime & 9 \\
\hline & Urban water resources & UWA & Pressure on regime & 6 \\
\hline & Urban land resources & ULA & Pressure on regime & 9 \\
\hline & Rural Land resources & LRE & Pressure on regime & 7 \\
\hline & Rural Water resources & WRE & Pressure on regime & 6 \\
\hline \multirow{9}{*}{$\begin{array}{l}\text { Technologies } \\
\text { (infrastructure, } \\
\text { regulatory, } \\
\text { accounting) }\end{array}$} & Peri urban farms & UF & $\begin{array}{l}\text { Competitor of urban } \\
\text { agriculture initiatives }\end{array}$ & 7 \\
\hline & LED grow lighting & LGL & Agricultural technology & 8 \\
\hline & Hydroponic methods & $\mathrm{HM}$ & Agricultural technology & 9 \\
\hline & $\begin{array}{l}\text { Vertical farming knowledge } \\
\text { technologies }\end{array}$ & VFT & Agricultural technology & 9 \\
\hline & Amsterdam climate and energy funds & ACEG & Fund & 7 \\
\hline & Common Agricultural Policy & CAP & $\begin{array}{l}\text { Supporting the development } \\
\text { of agricultural technologies }\end{array}$ & 7 \\
\hline & Milan urban food policy pact & MUFPP & $\begin{array}{l}\text { Supporting the development } \\
\text { of agricultural technologies }\end{array}$ & 8 \\
\hline & Land prices & LP & Pressure on regime & 9 \\
\hline & Catering services & CS & Market segment for initiatives & 6 \\
\hline
\end{tabular}


Table A4. Cont.

\begin{tabular}{|c|c|c|c|c|}
\hline Categories & Actant & Abbreviation & Main Role & DR \\
\hline \multirow{25}{*}{$\begin{array}{l}\text { Technologies } \\
\text { (infrastructure, } \\
\text { regulatory, } \\
\text { accounting) }\end{array}$} & Food banks & FB & Market segment for initiatives & 6 \\
\hline & Food policies & FPO & Target group & 7 \\
\hline & Urban food policies & UFP & $\begin{array}{l}\text { Supporting alternative } \\
\text { food-production methods }\end{array}$ & 8 \\
\hline & Healthy Weight Program & HWP & $\begin{array}{l}\text { Supporting alternative food } \\
\text { systems }\end{array}$ & 8 \\
\hline & Foreign markets & FM & Opportunity for initiatives & 8 \\
\hline & Agriculture knowledge system & AKS & Regulation of interactions & 7 \\
\hline & Agriculture Innovation system & AIS & Regulation of interactions & 7 \\
\hline & National subsidies for start-ups (PPP) & NSS & Fund & 9 \\
\hline & European fund subsidies & ES & Fund & 7 \\
\hline & Development plan & DP & $\begin{array}{l}\text { Regulation of urban system } \\
\text { development process }\end{array}$ & 6 \\
\hline & Food security & FS & $\begin{array}{l}\text { Objective for public-private } \\
\text { partnerships }\end{array}$ & 6 \\
\hline & History/World War & HWW & Pressure on regime & 7 \\
\hline & Diets & DIT & Opportunity for initiatives & 8 \\
\hline & Trends & TRE & Opportunity for initiatives & 8 \\
\hline & Agricultural extension services & AES & Regulation of interactions & 6 \\
\hline & Circular economy plans & CEP & Opportunity for initiatives & 8 \\
\hline & Environmental policies & EP & Opportunity for initiatives & 7 \\
\hline & Sustainable agriculture policies & SAP & Opportunity for initiatives & 8 \\
\hline & Land-use plan & LUP & $\begin{array}{c}\text { Regulation of spatial } \\
\text { development }\end{array}$ & 8 \\
\hline & $\begin{array}{l}\text { Export of agricultural products } \\
\text { regulations }\end{array}$ & EAP & Opportunity for initiatives & 7 \\
\hline & Technology export regulations & $\mathrm{TE}$ & Opportunity for initiatives & 7 \\
\hline & Business models & $\mathrm{BM}$ & $\begin{array}{l}\text { Regulation of interactions in } \\
\text { public-private partnerships }\end{array}$ & 9 \\
\hline & Vertical-farming equipment & VFA & Agricultural technology & 8 \\
\hline & Indoor gardens technologies & IN & $\begin{array}{l}\text { Vegetable production } \\
\text { technique }\end{array}$ & 8 \\
\hline & Climate change policies & CLC & Opportunity for initiatives & 7 \\
\hline \multirow{13}{*}{$\begin{array}{l}\text { Buildings and } \\
\text { structures }\end{array}$} & Brightbox & BB & Urban agriculture initiative & 7 \\
\hline & Urban farmers & UFS & Urban agriculture initiative & 6 \\
\hline & Greenhouses & $\mathrm{GH}$ & $\begin{array}{l}\text { Competitor of urban } \\
\text { agriculture initiatives }\end{array}$ & 7 \\
\hline & Supermarkets & SM & Distributor & 6 \\
\hline & Villa Regen & VR & Urban agriculture initiative & 7 \\
\hline & Dense urban areas & DUA & Opportunity for initiatives & 8 \\
\hline & Restaurants & RES & Opportunity for initiatives & 7 \\
\hline & Buildings & BUI & Opportunity for initiatives & 6 \\
\hline & Abandoned buildings & $\mathrm{AB}$ & Opportunity for initiatives & 8 \\
\hline & Roof top gardens & RTG & Urban greening initiative & 6 \\
\hline & Community gardening & CGA & Urban gardening initiative & 6 \\
\hline & Attractiveness of the city & ATC & $\begin{array}{l}\text { Attracting investors and } \\
\text { talents }\end{array}$ & 7 \\
\hline & Green facades & GF & Urban greening initiative & 6 \\
\hline
\end{tabular}


Table A4. Cont.

\begin{tabular}{|c|c|c|c|c|}
\hline Categories & Actant & Abbreviation & Main Role & $\overline{\text { DR }}$ \\
\hline \multirow{7}{*}{$\begin{array}{l}\text { Buildings and } \\
\text { structures }\end{array}$} & Public spaces & PS & $\begin{array}{l}\text { Space for advertisement and } \\
\text { promotion }\end{array}$ & 6 \\
\hline & Nursing homes & $\mathrm{NH}$ & Opportunity for initiatives & 7 \\
\hline & Neighborhoods & $\mathrm{NHO}$ & Opportunity for initiatives & 6 \\
\hline & Social housings & SHO & Opportunity for initiatives & 6 \\
\hline & Public libraries & LIB & Opportunity for initiatives & 6 \\
\hline & Urban infrastructures & UIF & $\begin{array}{l}\text { Infrastructures used in } \\
\text { providing services }\end{array}$ & 7 \\
\hline & High-tech indoor farming technologies & HTI & $\begin{array}{l}\text { Required technologies for } \\
\text { initiatives }\end{array}$ & 8 \\
\hline
\end{tabular}

Table A5. Ucinet statistics for analyzing the betweenness centrality of actors with a degree of relevance (DR) higher than 6 in transition process to HTUA in Amsterdam.

\begin{tabular}{|c|c|c|c|c|c|c|c|c|c|c|}
\hline & & $\begin{array}{c}1 \\
\text { Degree }\end{array}$ & $\begin{array}{c}2 \\
\text { 2local }\end{array}$ & $\begin{array}{c}3 \\
\text { BetaCent }\end{array}$ & $\begin{array}{c}4 \\
\text { 2Step }\end{array}$ & $\begin{array}{c}5 \\
\text { ARD }\end{array}$ & $\begin{array}{c}6 \\
\text { Closeness }\end{array}$ & $\begin{array}{c}7 \\
\text { Eigenvec }\end{array}$ & $\begin{array}{c}8 \\
\text { Between }\end{array}$ & $\begin{array}{c}9 \\
\text { 2StepB }\end{array}$ \\
\hline 1 & PHS & 242.000 & $33,190.000$ & $45,329.875$ & 68.000 & 68.000 & 68.000 & 1.000 & 46.382 & 46.382 \\
\hline 2 & HTAA & 192.000 & $27,178.000$ & $37,011.016$ & 68.000 & 64.000 & 76.000 & 0.817 & 30.593 & 30.593 \\
\hline 3 & $\mathrm{SCO}$ & 174.000 & $25,900.000$ & $35,334.367$ & 68.000 & 61.500 & 81.000 & 0.780 & 15.514 & 15.514 \\
\hline 4 & SUS & 164.000 & $23,210.000$ & $31,482.305$ & 68.000 & 61.500 & 81.000 & 0.695 & 18.290 & 18.290 \\
\hline 5 & SME & 196.000 & $26,918.000$ & $36,801.707$ & 68.000 & 65.500 & 73.000 & 0.812 & 33.245 & 33.245 \\
\hline 6 & LED & 166.000 & $23,600.000$ & $32,162.184$ & 68.000 & 62.500 & 79.000 & 0.710 & 23.712 & 23.712 \\
\hline 7 & HTT & 200.000 & $28,312.000$ & $38,629.246$ & 68.000 & 65.000 & 74.000 & 0.852 & 33.711 & 33.711 \\
\hline 8 & HTI & 182.000 & $25,494.000$ & $34,663.375$ & 68.000 & 64.000 & 76.000 & 0.765 & 29.636 & 29.636 \\
\hline 9 & $\mathrm{BB}$ & 118.000 & $17,406.000$ & $23,501.486$ & 68.000 & 53.000 & 98.000 & 0.519 & 8.510 & 8.510 \\
\hline 10 & MET & 100.000 & $14,672.000$ & $19,881.988$ & 68.000 & 48.000 & 108.000 & 0.439 & 2.981 & 2.981 \\
\hline 11 & IKEA & 42.000 & 6428.000 & 8517.175 & 68.000 & 41.500 & 121.000 & 0.188 & 0.717 & 0.717 \\
\hline 12 & WUR & 210.000 & $29,934.000$ & $40,890.039$ & 68.000 & 63.500 & 77.000 & 0.902 & 21.826 & 21.826 \\
\hline 13 & AMS & 102.000 & $15,192.000$ & $20,538.977$ & 68.000 & 52.000 & 100.000 & 0.453 & 7.042 & 7.042 \\
\hline 14 & HVA & 128.000 & $19,808.000$ & $26,829.203$ & 68.000 & 56.000 & 92.000 & 0.592 & 6.442 & 6.442 \\
\hline 15 & EI & 152.000 & $22,452.000$ & $30,519.018$ & 68.000 & 61.000 & 82.000 & 0.673 & 16.601 & 16.601 \\
\hline 16 & $\mathrm{GH}$ & 174.000 & $25,404.000$ & $34,637.102$ & 68.000 & 60.000 & 84.000 & 0.764 & 18.094 & 18.094 \\
\hline 17 & FAR & 150.000 & $22,512.000$ & $30,672.201$ & 68.000 & 58.000 & 88.000 & 0.677 & 12.612 & 12.612 \\
\hline 18 & HTF & 132.000 & $19,004.000$ & $25,493.309$ & 68.000 & 54.000 & 96.000 & 0.562 & 11.393 & 11.393 \\
\hline 19 & MUN & 156.000 & $22,154.000$ & $30,107.504$ & 68.000 & 60.500 & 83.000 & 0.664 & 20.588 & 20.588 \\
\hline 20 & KIG & 52.000 & 8414.000 & $11,303.452$ & 68.000 & 44.000 & 116.000 & 0.250 & 0.808 & 0.808 \\
\hline 21 & IMM & 36.000 & 5586.000 & 7450.183 & 68.000 & 41.000 & 122.000 & 0.164 & 0.531 & 0.531 \\
\hline 22 & MIN & 166.000 & $24,380.000$ & $33,312.523$ & 68.000 & 59.000 & 86.000 & 0.735 & 16.232 & 16.232 \\
\hline 23 & VWS & 148.000 & $21,626.000$ & $29,367.275$ & 68.000 & 59.500 & 85.000 & 0.648 & 15.550 & 15.550 \\
\hline 24 & LNV & 194.000 & $28,038.000$ & $38,362.977$ & 68.000 & 62.000 & 80.000 & 0.847 & 21.010 & 21.010 \\
\hline 25 & $\mathrm{OCW}$ & 99.000 & $14,795.000$ & $20,190.469$ & 68.000 & 50.500 & 103.000 & 0.446 & 4.636 & 4.636 \\
\hline 26 & $\mathrm{PP}$ & 90.000 & $13,724.000$ & $18,557.359$ & 68.000 & 49.000 & 106.000 & 0.410 & 3.565 & 3.565 \\
\hline 27 & NGF & 118.000 & $18,406.000$ & $24,966.742$ & 68.000 & 54.000 & 96.000 & 0.551 & 5.829 & 5.829 \\
\hline 28 & SCS & 106.000 & $16,452.000$ & $22,381.275$ & 68.000 & 51.500 & 101.000 & 0.494 & 3.863 & 3.863 \\
\hline 29 & SUM & 110.000 & $15,628.000$ & $21,171.645$ & 68.000 & 51.500 & 101.000 & 0.467 & 6.881 & 6.881 \\
\hline 30 & PPS & 96.000 & $14,924.000$ & $20,039.371$ & 68.000 & 51.000 & 102.000 & 0.442 & 3.118 & 3.118 \\
\hline 31 & $\mathrm{VH}$ & 158.000 & $23,256.000$ & $31,454.830$ & 68.000 & 57.500 & 89.000 & 0.694 & 13.515 & 13.515 \\
\hline 32 & VR & 70.000 & $11,148.000$ & $14,790.247$ & 68.000 & 45.500 & 113.000 & 0.326 & 1.801 & 1.801 \\
\hline 33 & CAP & 138.000 & $21,438.000$ & $29,060.133$ & 68.000 & 56.000 & 92.000 & 0.641 & 10.313 & 10.313 \\
\hline
\end{tabular}


Table A5. Cont.

\begin{tabular}{|c|c|c|c|c|c|c|c|c|c|c|}
\hline & & $\begin{array}{c}1 \\
\text { Degree }\end{array}$ & $\begin{array}{c}2 \\
\text { 2local }\end{array}$ & $\begin{array}{c}3 \\
\text { BetaCent }\end{array}$ & $\begin{array}{c}4 \\
\text { 2Step }\end{array}$ & $\begin{array}{c}5 \\
\text { ARD }\end{array}$ & $\begin{array}{c}6 \\
\text { Closeness }\end{array}$ & $\begin{array}{c}7 \\
\text { Eigenvec }\end{array}$ & $\begin{array}{c}8 \\
\text { Between }\end{array}$ & $\begin{array}{c}9 \\
\text { 2StepB }\end{array}$ \\
\hline 34 & MFPP & 122.000 & $17,814.000$ & $24,078.209$ & 68.000 & 55.500 & 93.000 & 0.531 & 10.017 & 10.017 \\
\hline 35 & UFP & 206.000 & $29,192.000$ & $39,840.840$ & 68.000 & 65.000 & 74.000 & 0.879 & 28.988 & 28.988 \\
\hline 36 & ACR & 136.000 & $21,080.000$ & $28,439.350$ & 68.000 & 56.500 & 91.000 & 0.628 & 7.885 & 7.885 \\
\hline 37 & AIU & 122.000 & $18,206.000$ & $24,665.016$ & 68.000 & 56.500 & 91.000 & 0.544 & 10.337 & 10.337 \\
\hline 38 & LUP & 146.000 & $21,564.000$ & $29,378.986$ & 68.000 & 57.500 & 89.000 & 0.648 & 11.688 & 11.688 \\
\hline 39 & RCS & 78.000 & $12,010.000$ & $15,916.025$ & 68.000 & 48.000 & 108.000 & 0.351 & 2.459 & 2.459 \\
\hline 40 & DUA & 108.000 & $15,588.000$ & $20,864.031$ & 68.000 & 50.000 & 104.000 & 0.460 & 6.747 & 6.747 \\
\hline 41 & TOR & 86.000 & $12,444.000$ & $16,651.619$ & 68.000 & 47.500 & 109.000 & 0.367 & 2.881 & 2.881 \\
\hline 42 & NAG & 188.000 & $27,306.000$ & $37,346.754$ & 68.000 & 62.000 & 80.000 & 0.824 & 18.783 & 18.783 \\
\hline 43 & $\mathrm{CAB}$ & 102.000 & $16,144.000$ & $21,858.406$ & 68.000 & 52.000 & 100.000 & 0.483 & 3.764 & 3.764 \\
\hline 44 & VAB & 78.000 & $11,780.000$ & $15,823.654$ & 68.000 & 49.500 & 105.000 & 0.349 & 3.243 & 3.243 \\
\hline 45 & AKIS & 182.000 & $26,898.000$ & $36,610.453$ & 68.000 & 62.000 & 80.000 & 0.808 & 18.054 & 18.054 \\
\hline 46 & NS & 136.000 & $20,758.000$ & $28,125.969$ & 68.000 & 58.500 & 87.000 & 0.621 & 10.641 & 10.641 \\
\hline 47 & NDP & 170.000 & $25,528.000$ & $34,717.082$ & 68.000 & 61.500 & 81.000 & 0.766 & 17.248 & 17.248 \\
\hline 48 & ASDP & 164.000 & $24,790.000$ & $33,624.438$ & 68.000 & 61.500 & 81.000 & 0.742 & 19.285 & 19.285 \\
\hline 49 & CEDP & 162.000 & $24,128.000$ & $32,808.691$ & 68.000 & 61.500 & 81.000 & 0.724 & 20.156 & 20.156 \\
\hline 50 & $\mathrm{CC}$ & 132.000 & $19,710.000$ & $26,616.111$ & 68.000 & 58.000 & 88.000 & 0.587 & 11.072 & 11.072 \\
\hline 51 & TD & 94.000 & $13,180.000$ & $17,651.750$ & 68.000 & 51.000 & 102.000 & 0.389 & 7.986 & 7.986 \\
\hline 52 & FV & 148.000 & $22,668.000$ & $30,739.240$ & 68.000 & 59.500 & 85.000 & 0.678 & 11.828 & 11.828 \\
\hline 53 & BAN & 130.000 & $19,190.000$ & $26,048.754$ & 68.000 & 56.000 & 92.000 & 0.575 & 11.165 & 11.165 \\
\hline 54 & ENP & 144.000 & $22,130.000$ & $30,088.311$ & 68.000 & 58.500 & 87.000 & 0.664 & 10.268 & 10.268 \\
\hline 55 & EXT & 104.000 & $16,668.000$ & $22,497.492$ & 68.000 & 51.000 & 102.000 & 0.497 & 3.642 & 3.642 \\
\hline 56 & EXP & 112.000 & $18,296.000$ & $24,708.787$ & 68.000 & 50.000 & 104.000 & 0.546 & 2.221 & 2.221 \\
\hline 57 & MAN & 92.000 & $13,880.000$ & $18,675.158$ & 68.000 & 48.500 & 107.000 & 0.412 & 4.268 & 4.268 \\
\hline 58 & WEA & 131.000 & $20,387.000$ & $27,392.762$ & 68.000 & 53.000 & 98.000 & 0.605 & 4.711 & 4.711 \\
\hline 59 & LAM & 144.000 & $20,884.000$ & $28,428.873$ & 68.000 & 56.500 & 91.000 & 0.627 & 12.401 & 12.401 \\
\hline 60 & UIN & 166.000 & $24,348.000$ & $32,974.625$ & 68.000 & 60.500 & 83.000 & 0.728 & 16.806 & 16.806 \\
\hline 61 & URE & 138.000 & $20,444.000$ & $27,554.643$ & 68.000 & 57.000 & 90.000 & 0.608 & 13.142 & 13.142 \\
\hline 62 & PS & 108.000 & $17,088.000$ & $23,101.521$ & 68.000 & 54.000 & 96.000 & 0.510 & 4.584 & 4.584 \\
\hline 63 & FB & 84.000 & $13,324.000$ & $17,999.928$ & 68.000 & 49.500 & 105.000 & 0.397 & 3.207 & 3.207 \\
\hline 64 & AES & 112.000 & $18,300.000$ & $24,734.416$ & 68.000 & 51.500 & 101.000 & 0.546 & 2.419 & 2.419 \\
\hline 65 & NGON & 84.000 & $12,920.000$ & $17,316.604$ & 68.000 & 51.500 & 101.000 & 0.382 & 5.174 & 5.174 \\
\hline 66 & KFR & 64.000 & 9812.000 & $13,174.391$ & 68.000 & 46.000 & 112.000 & 0.291 & 1.868 & 1.868 \\
\hline 67 & LAR & 186.000 & $27,402.000$ & $37,273.309$ & 68.000 & 60.500 & 83.000 & 0.823 & 16.080 & 16.080 \\
\hline 68 & WRE & 176.000 & $25,976.000$ & $35,409.930$ & 68.000 & 60.000 & 84.000 & 0.781 & 15.229 & 15.229 \\
\hline 69 & CLC & 174.000 & $24,910.000$ & $34,055.500$ & 68.000 & 62.000 & 80.000 & 0.751 & 25.212 & 25.212 \\
\hline
\end{tabular}

(1. Degree: Degree of centrality; 2. 2local: 2-local eigenvector centrality; 3. BetaCent: Beta centrality; 4. 2Step: 2-step reach; 5. ARD: Average Relative Distance; 6. Closeness: Closeness centrality; 7. Eigenvec: Eigenvector centrality; 8. Between: Betweenness centrality 9. 2StepB: 2-step betweenness centrality).

For the quantification of relationships, a matrix table was made to quantify the relationships between actants involved. It included the rated relationships of 70 actants with all other actants. They were rated as follows: $0=$ not connected, $2=$ indirect connection and $4=$ connected. The table below is a section of the table to show how this matrix table was prepared. 
Path work of transition

(Socio-technical regime and its driving forces)

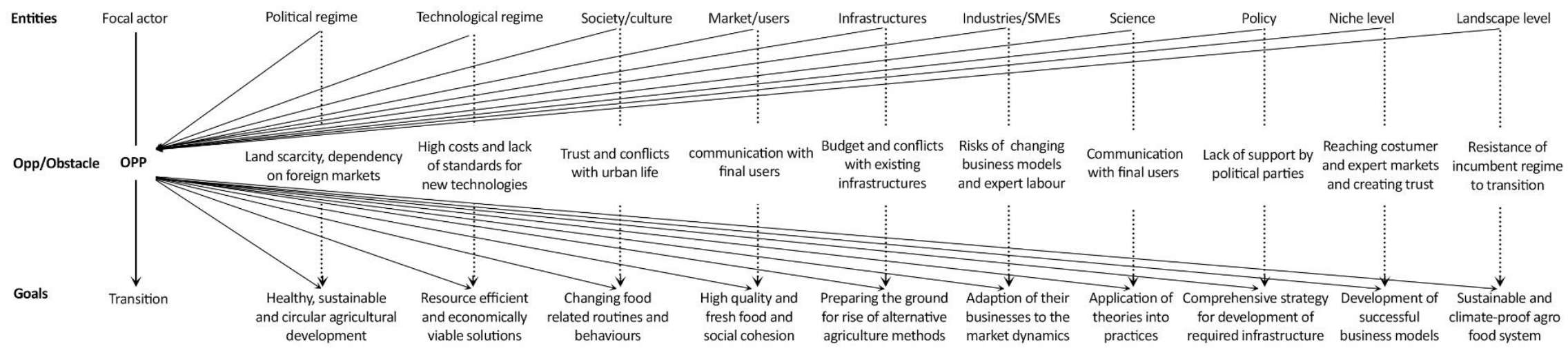

Societal transformation towards transition

(Development process for transition of agro food production system)

Figure A1. Translation of transition to HTUA in the Amsterdam metropolitan region. Adapted from Callon, 1986 [38]. 
Table A6. A section of the matrix table that was used for the quantification of relationships among actants involved in transition.

\begin{tabular}{|c|c|c|c|c|c|c|c|c|c|c|c|c|c|c|}
\hline & PHS & HTAA & SCO & SUS & SME & LED & HTT & HTI & BB & MET & IKEA & WUR & AMS & HVA \\
\hline PHS & 0 & 4 & 4 & 4 & 4 & 4 & 4 & 4 & 4 & 2 & 2 & 4 & 4 & 4 \\
\hline HTAA & 4 & 0 & 4 & 4 & 4 & 4 & 4 & 4 & 4 & 4 & 4 & 4 & 2 & 2 \\
\hline SCO & 4 & 4 & 0 & 4 & 4 & 2 & 4 & 4 & 4 & 2 & 0 & 2 & 0 & 2 \\
\hline SUS & 4 & 4 & 4 & 0 & 2 & 4 & 4 & 2 & 0 & 4 & 0 & 4 & 2 & 2 \\
\hline SME & 4 & 4 & 4 & 2 & 0 & 2 & 4 & 2 & 2 & 0 & 2 & 4 & 2 & 4 \\
\hline LED & 4 & 4 & 2 & 4 & 2 & 0 & 2 & 4 & 4 & 2 & 0 & 2 & 2 & 2 \\
\hline HTT & 4 & 4 & 4 & 4 & 4 & 2 & 0 & 4 & 4 & 4 & 4 & 2 & 2 & 2 \\
\hline HTI & 4 & 4 & 4 & 2 & 2 & 4 & 4 & 0 & 0 & 2 & 0 & 4 & 2 & 2 \\
\hline BB & 4 & 4 & 4 & 0 & 2 & 4 & 4 & 0 & 0 & 0 & 0 & 2 & 0 & 2 \\
\hline MET & 2 & 4 & 2 & 4 & 0 & 2 & 4 & 2 & 0 & 0 & 0 & 4 & 0 & 0 \\
\hline IKEA & 2 & 4 & 0 & 0 & 2 & 0 & 4 & 0 & 0 & 0 & 0 & 0 & 0 & 0 \\
\hline WUR & 4 & 4 & 2 & 4 & 4 & 2 & 2 & 4 & 2 & 4 & 0 & 0 & 4 & 4 \\
\hline AMS & 4 & 2 & 0 & 2 & 2 & 2 & 2 & 2 & 0 & 0 & 0 & 4 & 0 & 4 \\
\hline HVA & 4 & 2 & 2 & 2 & 4 & 2 & 2 & 2 & 2 & 0 & 0 & 4 & 4 & 0 \\
\hline EI & 4 & 2 & 2 & 2 & 4 & 2 & 2 & 2 & 2 & 2 & 0 & 4 & 4 & 4 \\
\hline GH & 4 & 4 & 4 & 2 & 2 & 4 & 4 & 0 & 2 & 0 & 0 & 4 & 0 & 2 \\
\hline FAR & 4 & 4 & 4 & 0 & 2 & 4 & 2 & 0 & 4 & 0 & 0 & 4 & 0 & 2 \\
\hline HTF & 4 & 4 & 4 & 4 & 2 & 4 & 2 & 4 & 0 & 4 & 4 & 2 & 0 & 0 \\
\hline MUN & 4 & 4 & 2 & 4 & 2 & 2 & 2 & 4 & 0 & 0 & 0 & 2 & 4 & 4 \\
\hline KIG & 4 & 2 & 2 & 0 & 0 & 2 & 0 & 0 & 4 & 0 & 0 & 4 & 2 & 0 \\
\hline IMM & 2 & 0 & 0 & 0 & 2 & 0 & 2 & 2 & 0 & 0 & 0 & 0 & 2 & 0 \\
\hline MIN & 4 & 2 & 4 & 0 & 4 & 0 & 2 & 2 & 2 & 0 & 0 & 4 & 0 & 0 \\
\hline VWS & 4 & 4 & 4 & 2 & 2 & 2 & 4 & 2 & 2 & 0 & 0 & 4 & 4 & 4 \\
\hline LNV & 4 & 2 & 4 & 2 & 4 & 4 & 4 & 2 & 4 & 0 & 0 & 4 & 0 & 4 \\
\hline OCW & 2 & 2 & 2 & 2 & 0 & 0 & 4 & 2 & 2 & 0 & 0 & 4 & 4 & 4 \\
\hline PP & 2 & 2 & 2 & 0 & 4 & 0 & 2 & 2 & 0 & 0 & 0 & 4 & 2 & 0 \\
\hline NGF & 4 & 4 & 4 & 2 & 4 & 2 & 4 & 4 & 0 & 0 & 0 & 0 & 0 & 0 \\
\hline SCS & 2 & 0 & 2 & 4 & 0 & 0 & 4 & 4 & 0 & 4 & 0 & 4 & 0 & 0 \\
\hline SUM & 2 & 0 & 0 & 0 & 4 & 0 & 2 & 2 & 4 & 4 & 0 & 0 & 0 & 0 \\
\hline PPS & 4 & 2 & 4 & 2 & 4 & 4 & 2 & 2 & 0 & 0 & 0 & 0 & 2 & 0 \\
\hline VH & 4 & 4 & 4 & 4 & 2 & 4 & 4 & 2 & 4 & 4 & 2 & 4 & 0 & 0 \\
\hline VR & 4 & 2 & 0 & 0 & 4 & 2 & 4 & 2 & 0 & 0 & 0 & 0 & 0 & 0 \\
\hline CAP & 2 & 4 & 4 & 2 & 4 & 2 & 4 & 4 & 2 & 4 & 2 & 4 & 0 & 0 \\
\hline MFPP & 2 & 2 & 2 & 0 & 4 & 0 & 2 & 2 & 2 & 0 & 0 & 2 & 0 & 0 \\
\hline UFP & 4 & 2 & 2 & 2 & 4 & 4 & 4 & 4 & 0 & 0 & 2 & 4 & 2 & 4 \\
\hline ACR & 4 & 2 & 4 & 2 & 4 & 4 & 4 & 2 & 4 & 4 & 0 & 4 & 4 & 4 \\
\hline AIU & 4 & 0 & 0 & 2 & 4 & 4 & 0 & 2 & 0 & 4 & 0 & 4 & 4 & 4 \\
\hline LUP & 2 & 0 & 2 & 2 & 4 & 4 & 2 & 2 & 0 & 0 & 0 & 4 & 2 & 2 \\
\hline RCS & 4 & 2 & 0 & 4 & 4 & 2 & 2 & 4 & 4 & 0 & 0 & 2 & 0 & 0 \\
\hline DUA & 4 & 4 & 0 & 2 & 4 & 4 & 4 & 4 & 4 & 0 & 4 & 0 & 0 & 0 \\
\hline TOR & 4 & 2 & 0 & 4 & 4 & 2 & 0 & 2 & 4 & 0 & 0 & 0 & 0 & 0 \\
\hline NAG & 4 & 4 & 4 & 4 & 2 & 2 & 4 & 2 & 2 & 0 & 0 & 0 & 2 & 2 \\
\hline САВ & 2 & 0 & 4 & 2 & 4 & 0 & 2 & 4 & 0 & 0 & 0 & 4 & 0 & 0 \\
\hline
\end{tabular}


Table A6. Cont.

\begin{tabular}{|c|c|c|c|c|c|c|c|c|c|c|c|c|c|c|}
\hline & PHS & HTAA & SCO & SUS & SME & LED & HTT & HTI & BB & MET & IKEA & WUR & AMS & HVA \\
\hline VAB & 2 & 0 & 0 & 4 & 2 & 0 & 2 & 4 & 0 & 0 & 0 & 2 & 4 & 2 \\
\hline AKIS & 4 & 4 & 4 & 4 & 2 & 4 & 4 & 4 & 2 & 4 & 0 & 2 & 4 & 4 \\
\hline NS & 4 & 4 & 4 & 4 & 2 & 2 & 4 & 2 & 2 & 0 & 0 & 4 & 2 & 2 \\
\hline NDP & 4 & 2 & 4 & 2 & 4 & 2 & 4 & 4 & 0 & 0 & 0 & 4 & 0 & 2 \\
\hline ASDP & 4 & 4 & 4 & 2 & 2 & 2 & 4 & 4 & 0 & 4 & 2 & 4 & 2 & 2 \\
\hline CEDP & 4 & 4 & 4 & 2 & 2 & 4 & 4 & 2 & 0 & 4 & 2 & 4 & 2 & 4 \\
\hline CC & 4 & 4 & 2 & 4 & 2 & 2 & 2 & 2 & 0 & 0 & 0 & 4 & 4 & 2 \\
\hline TD & 4 & 2 & 0 & 4 & 2 & 2 & 0 & 4 & 4 & 4 & 4 & 2 & 2 & 0 \\
\hline FV & 4 & 4 & 4 & 4 & 2 & 2 & 4 & 4 & 2 & 4 & 0 & 4 & 2 & 2 \\
\hline BAN & 4 & 4 & 2 & 4 & 4 & 2 & 4 & 2 & 4 & 4 & 0 & 4 & 0 & 2 \\
\hline ENP & 4 & 4 & 2 & 2 & 4 & 2 & 4 & 2 & 0 & 4 & 0 & 4 & 2 & 2 \\
\hline EXT & 4 & 4 & 2 & 2 & 4 & 4 & 4 & 2 & 2 & 0 & 0 & 4 & 0 & 2 \\
\hline EXP & 4 & 4 & 4 & 0 & 4 & 4 & 2 & 0 & 0 & 0 & 0 & 4 & 0 & 2 \\
\hline MAN & 4 & 4 & 0 & 4 & 4 & 4 & 4 & 2 & 0 & 4 & 4 & 2 & 0 & 2 \\
\hline WEA & 4 & 4 & 2 & 4 & 2 & 4 & 4 & 4 & 4 & 4 & 0 & 0 & 0 & 0 \\
\hline LAM & 2 & 4 & 4 & 2 & 4 & 2 & 4 & 2 & 4 & 4 & 0 & 2 & 0 & 4 \\
\hline UIN & 4 & 2 & 4 & 4 & 4 & 2 & 2 & 4 & 2 & 0 & 0 & 4 & 0 & 2 \\
\hline URE & 4 & 4 & 4 & 4 & 4 & 4 & 2 & 2 & 0 & 0 & 2 & 2 & 0 & 0 \\
\hline PS & 4 & 2 & 4 & 2 & 4 & 2 & 2 & 2 & 0 & 0 & 0 & 2 & 2 & 2 \\
\hline FB & 2 & 0 & 2 & 0 & 2 & 4 & 0 & 0 & 0 & 0 & 0 & 4 & 0 & 0 \\
\hline AES & 4 & 4 & 4 & 0 & 4 & 4 & 4 & 0 & 0 & 0 & 0 & 4 & 0 & 4 \\
\hline NGON & 4 & 2 & 2 & 4 & 2 & 2 & 0 & 4 & 2 & 0 & 0 & 4 & 2 & 4 \\
\hline KFR & 2 & 2 & 0 & 4 & 0 & 2 & 2 & 4 & 0 & 4 & 0 & 0 & 0 & 0 \\
\hline LAR & 4 & 2 & 2 & 2 & 2 & 4 & 4 & 4 & 4 & 0 & 0 & 4 & 4 & 4 \\
\hline WRE & 4 & 2 & 2 & 2 & 2 & 0 & 4 & 4 & 4 & 0 & 0 & 4 & 4 & 4 \\
\hline CLC & 4 & 2 & 2 & 2 & 2 & 2 & 4 & 4 & 4 & 2 & 2 & 4 & 4 & 4 \\
\hline
\end{tabular}

Table A7. Role of different actants in the development of HTUA in Amsterdam.

\begin{tabular}{|c|c|}
\hline Type of Actants & Role of Actants in Transition \\
\hline \multirow{2}{*}{ National government } & Formulation of national polices for sustainable development and circular economy \\
\hline & Allocation of public funds for sustainable projects \\
\hline \multirow{5}{*}{ Local government } & Defining action plans \\
\hline & Working with initiatives through PPPs \\
\hline & Providing funds for initiatives \\
\hline & Formulation of municipal policies \\
\hline & Collaboration with Food Council MRA \\
\hline SOCs & None of the 38 companies that the Dutch state holds shares in played a major role \\
\hline \multirow{3}{*}{ Private businesses } & $\begin{array}{c}\text { Main developers of multifunctional HTUA practices with centrality of social and } \\
\text { environmental aspects }\end{array}$ \\
\hline & Investors in HTUA practices \\
\hline & Research and development activities in HTUA \\
\hline Non-profit organizations & Collaboration with initiatives in the development of multifunctional HTUA practices \\
\hline Knowledge institutes & $\begin{array}{l}\text { Working with businesses and government for the development of new technologies and } \\
\text { knowledge creation }\end{array}$ \\
\hline
\end{tabular}


Table A7. Cont.

\begin{tabular}{|c|c|}
\hline Type of Actants & Role of Actants in Transition \\
\hline $\begin{array}{l}\text { Governmental } \\
\text { organizations }\end{array}$ & $\begin{array}{l}\text { TKI (top consortium for knowledge and innovation), DLO (agricultural research service), } \\
\text { and AWT (advisory council for science and technology policy) work to remove barriers to } \\
\text { collaborations between businesses, the government, and knowledge institutes }\end{array}$ \\
\hline Social groups & Advocates of alternative food-production methods \\
\hline Individual citizens & $\begin{array}{l}\text { Demand for socially and environmentally sustainable food-production methods and } \\
\text { products }\end{array}$ \\
\hline \multirow{2}{*}{ Technologies } & Technologies and knowledge are produced through R\&D projects \\
\hline & Entering and competing in the global market \\
\hline Public policies & $\begin{array}{c}\text { Encouraging the development of business cases with centrality of social and } \\
\text { environmental aspects of HTUA practices }\end{array}$ \\
\hline Development plans & Giving space for the development of small-scale niche projects \\
\hline Urban regulations & Restricting large-scale application of technologies \\
\hline $\begin{array}{c}\text { Architectural } \\
\text { visualizations }\end{array}$ & Effective in attracting investors and the public's attention \\
\hline Soil & $\begin{array}{l}\text { Due to the existence of limited resources of very high quality in the Netherlands, to expand } \\
\text { the productivity of agricultural sector, many agricultural technologies such as greenhouse } \\
\text { technologies were developed, which are considered the basic technologies used in HTUA }\end{array}$ \\
\hline
\end{tabular}

\section{References}

1. Petersen, W.; Hofstee, E.W. Rural Life and Rural Welfare in the Netherlands. Popul. Stud. 1958, 11, 272. [CrossRef]

2. Berkhout, P.; van Bruchem, C. Agricultural Economic Report 2009 of the Netherlands: Summary; LEI WUR: Wageninegn, The Netherlands, 2009.

3. Van Der Heidea, C.M.; Silvisa, H.J.; Heijmanb, W.J. Agriculture in The Netherlands: Its Recent Past, Current State and Perspectives. Appl. Stud. Agribus. Commer. 2011, 5, 23-28. [CrossRef] [PubMed]

4. Douw, L.; Post, J. Growing Strong: The Development of the Dutch Agricultural Sector; Background and Prospects; Agricultural Economics Research Institute (LEI): The Hague, The Netherlands, 2000.

5. Diogo, V.; Reidsma, P.; Schaap, B.; Koomen, E. Analysing Climate Change Impacts on Local Economic Performance of Dutch Agricultural Systems; Deltas in Times of Climate Change II: Rotterdam, The Netherlands, 2014.

6. Kramer, K.J.; Meeusen, M. Sustainability in the Agrofood Sector; DIAS Report; Life Cycle Assessment in the Agri-food sector: Horsens, Denmark, 2004.

7. Renting, H.; Wiskerke, J.S. New Emerging Roles for Public Institutions and Civil Society in the Promotion of Sustainable Local Agro-Food Systems; European IFSA Symposium: Vienna, Austria, 2010.

8. Hosseinifarhangi, M.; Turvani, M.; Van Der Valk, A.; Carsjens, G. Technology-Driven Transition in Urban Food Production Practices: A Case Study of Shanghai. Sustainability 2019, 11, 6070. [CrossRef]

9. Barbosa, G.L.; Gadelha, F.D.A.; Kublik, N.; Proctor, A.; Reichelm, L.; Weissinger, E.; Wohlleb, G.M.; Halden, R.U. Comparison of Land, Water, and Energy Requirements of Lettuce Grown Using Hydroponic vs. Conventional Agricultural Methods. Int. J. Environ. Res. Public Health 2015, 12, 6879-6891. [CrossRef] [PubMed]

10. Bayley, J.; Yu, M.; Frediani, K. Sustainable food production using high density vertical growing (Verticropi). Acta Hortic. 2011, 95-104. [CrossRef]

11. Kalantari, F.; Tahir, O.M.; Joni, R.A.; Fatemi, E. Opportunities and Challenges in Sustainability of Vertical Farming: A Review. J. Landsc. Ecol. 2018, 11, 35-60. [CrossRef]

12. Benke, K.; Tomkins, B. Future food-production systems: Vertical farming and controlled-environment agriculture. Sustain. Sci. Pr. Policy 2017, 13, 13-26. [CrossRef]

13. Gould, D.; Caplow, T. Building-integrated agriculture: A new approach to food production. In Metropolitan Sustainability; Woodhead Publishing: Cambridge, UK, 2012; pp. 147-170.

14. Lin, B.B.; Philpott, S.M.; Jha, S.; Liere, H. Urban Agriculture as a Productive Green Infrastructure for Environmental and Social Well-Being. In Sustainable Human-Nature Relations; Springer Science and Business Media LLC: Singapore, 2017; Volume 4, pp. 155-179. 
15. Benis, K.; Ferrao, P. Commercial farming within the urban built environment-Taking stock of an evolving field in northern countries. Glob. Food Secur. 2018, 17, 30-37. [CrossRef]

16. Geels, F.W. Technological transitions as evolutionary reconfiguration processes: A multi-level perspective and a case-study. Res. Policy 2002, 31, 1257-1274. [CrossRef]

17. Faik, I.; Thompson, M.; Walsham, G. Facing the Dilemmas of Development: Understanding Development Action through Actor-Network Theory; Centre for Development Informatics, Institute for Development Policy and Management: Manchester, UK, 2013.

18. Geels, F.W.; Schot, J. Typology of sociotechnical transition pathways. Res. Policy 2007, 36, 399-417. [CrossRef]

19. Law, J. Notes on the theory of the actor-network: Ordering, strategy, and heterogeneity. Syst. Pr. Action Res. 1992, 5, 379-393. [CrossRef]

20. Callon, M. Some Elements of a Sociology of Translation: Domestication of the Scallops and the Fishermen of St Brieuc Bay. Sociol. Rev. 1984, 32, 196-233. [CrossRef]

21. Blok, A.; Farías, I. Urban Cosmopolitics: Agencements, Assemblies, Atmospheres; Routledge: London, UK, 2016.

22. Hosseinifarhangi, M. Translation of Sociotechnical Transitions. A Comparative Study of the Integration of Agricultural Technologies into Urban Food Production Practices in Shanghai and Amsterdam. Ph.D. Thesis, University Iuav of Venice, Venice, Italy, 2019.

23. Melian, C.; Mähring, M. Lost and Gained in Translation: Adoption of Open Source Software Development at Hewlett-Packard; Springer: Boston, MA, USA, 2008; Volume 275, pp. 93-104.

24. Banerjee, C.; Adenaeuer, L. Up, Up and Away! The Economics of Vertical Farming. J. Agric. Stud. 2014, 2, 40. [CrossRef]

25. Besten, J.D. Vertical Farming Development; the Dutch Approach. In Plant Factory Using Artif; Elsevier BV: Amsterdam, The Netherlands, 2019; pp. 307-317.

26. Baiocchi, G.; Graizbord, D.; Rodríguez-Muñiz, M. Actor-Network Theory and the ethnographic imagination: An exercise in translation. Qual. Sociol. 2013, 36, 323-341. [CrossRef]

27. Doak, J.; Karadimitriou, N.; Karadimitriou, N. (Re)development, Complexity and Networks: A Framework for Research. Urban Stud. 2007, 44, 209-229. [CrossRef]

28. Gabriel, M.; Jacobs, K. The Post-Social Turn: Challenges for Housing Research. Hous. Stud. 2008, 23, 527-540. [CrossRef]

29. Collinge, C. Flat ontology and the deconstruction of scale: A response to Marston, Jones and Woodward. Trans. Inst. Br. Geogr. 2006, 31, 244-251. [CrossRef]

30. Latour, B. On Actor-Network Theory: A Few Clarifications. Soziale Welt 1996, 47, 369-381.

31. Paredis, E. Sustainability Transitions and the Nature of Technology. Found. Sci. 2010, 16, 195-225. [CrossRef]

32. Truffer, B.; Störmer, E.; Maurer, M.; Ruef, A. Local strategic planning processes and sustainability transitions in infrastructure sectors. Environ. Policy Gov. 2010, 20, 258-269. [CrossRef]

33. Lanford, H.; Imundo, L. Approaches to technological forecasting as a planning tool. Long Range Plan. 1974, 7, 49-58. [CrossRef]

34. Marsden, P.V. Survey Methods for Network Data. In The SAGE Handbook of Social Network Analysis; SAGE Publications Ltd: London, UK, 2015; pp. 370-388.

35. Quiédeville, S.; Slavova, P.; Touzard, J.-M.; Barjolle, D. Assessing the Role of the Research in the Transition to Organic Farming by Using the Actor Network Theory: Lessons from Two Case Studies in France and Bulgaria. In European IFSA Symposium; IFSA: Montpellier, France, 2018; Volume 13.

36. Schot, J.; Kanger, L.; Verbong, G. The roles of users in shaping transitions to new energy systems. Nat. Energy 2016, 1, 16054. [CrossRef]

37. Sopjani, L.; Stier, J.J.; Ritzén, S.; Hesselgren, M.; Georén, P. Involving users and user roles in the transition to sustainable mobility systems: The case of light electric vehicle sharing in Sweden. Transp. Res. Part D Transp. Environ. 2019, 71, 207-221. [CrossRef]

38. Callon, M.; Law, J.; Rip, A. How to study the force of science. In Mapping the Dynamics of Science and Technology; Palgrave Macmillan: London, UK, 1986; pp. 3-15.

(C) 2020 by the authors. Licensee MDPI, Basel, Switzerland. This article is an open access article distributed under the terms and conditions of the Creative Commons Attribution (CC BY) license (http://creativecommons.org/licenses/by/4.0/). 